\title{
Structural investigation of the catalytic activity of Fe(III) \\ and Mn(III) Schiff base complexes
}

Sabrina BENDIA ${ }^{\mathrm{a}, \mathrm{d}}$, Riadh BOURZAMI ${ }^{\mathrm{b}}$, Jean WEISS $^{\mathrm{c}}$ and Kamel OUARI*a

${ }^{a}$ Laboratoire d'Electrochimie, d'Ingénierie Moléculaire et de Catalyse Rédox (LEIMCR), Faculté de Technologie, Université Ferhat ABBAS Sétif 1, DZ-19000, Sétif, Algeria.

${ }^{b}$ Emerging materials unit, Ferhat Abbas University Setif 1, 19000 Algeria.

' Laboratoire de Chimie des Ligands à Architecture Contrôlée (CLAC), UMR 7177 CNRS-Université de Strasbourg, 4 rue Blaise Pascal, Strasbourg 67000 France.

${ }^{d}$ Institut de la Nutrition de l'Alimentation et des Technologies Agro-Alimentaires (INATAA), Université Frères Mentouri - Constantine 1.

*kamel_ouari@univ-setif.dz,.Tel :+213772487875

\begin{abstract}
Two novel manganese (III) and iron (III) complexes of an $N, N$-bis(1-naphthalidimine)- $O$ phenylenediamine ligand have been successfully synthesized and characterized by various analytical techniques including single crystal X-ray structure analysis. The ligand crystallizes in the monoclinic system with space group P2 $1 / \mathrm{c}$. The detailed analyses of Hirschfeld surface and fingerprint plots provide insight into the nature of non-covalent interactions in the ligand. Experimental data have been complemented and interpreted in the light of Density Functional Theory calculation was performed using the B3LYP method concerning molecular geometries, vibrational frequencies and electrochemical potentials. Cyclic voltammetry in dimethylformamide revealed reversible redox processes in both complexes, suggesting possible catalytic reactivity involving electron transfer process for these complexes. The catalytic efficiency and selectivity of manganese (III) and iron (III) complexes was tested in the oxidation of cyclohexene with molecular oxygen. The results show that the catalytic performance depends on the nature of metal, the most efficient catalyst in the presence of $\mathrm{O}_{2}$ being the iron (III) complex. A plausible mechanism for cyclohexene oxidation by complexes is proposed and discussed hereafter.
\end{abstract}

Keywords: Crystal structure; Iron complex; Manganese complex; DFT calculations; Electrochemical; Oxidation catalysis.

\section{Introduction}

Schiff base ligands are well known for coordinating many elements and stabilizing these in various oxidation states. Schiff bases have been used in the preparation of many potential 
drugs and possess a broad spectrum of biological activities [1-3] and previous reports have established that after complexation of transition metal ions the antimicrobial activity was generally increased [4]. Amidst ligand for transition metals, pincer ligands play an important role and their complexes have attracted tremendous interest due to their high stability, activity and versatility [5].

The chemistry of iron and manganese complexes has been widely investigated due to their involvement in a variety of biological redox systems including peroxidases [6], catalases [7], superoxide dismutases [8], dioxygenases [9] and lipoxidases [10]. Manganese and iron chelate complexes are attractive because of their potential use as catalysts in oxidation reactions [11]. Hence, they are effective catalysts in alkanes [12] amines [13], alcohols [14] and sulfides [15] oxidation and electron transfer in a range of metabolic reactions [16], electrochemical sensors and electroluminescent devices [17] or novel magnetic molecular materials [18].

Iron (III) and manganese (III) complexes, by comparison to other transition metal ions, are usually considered as the most important representative class of complexes exhibiting catalytic and electrocatalytic activity in the epoxidation of alkenes [19-21]. For both metals, the generally accepted catalytically active species for the epoxidation reactions with different substrates and oxygen atom donors are metal-oxo species.

Oxidation reactions are critical to numerous chemical transformations, and thus the development of oxidation reactions that rely on renewable and environmentally friendly oxidants is a concern for all areas of chemistry $[22,23]$. Indeed, molecular oxygen is an ideal oxidant in many ways as the only byproduct of its reduction is water. Dioxygen is non-toxic under most conditions, and its reduction potential is more than sufficient to drive many chemical transformations [24-27]. The coordination of $\mathrm{O}_{2}$ to a transition metal center also facilitates oxygen transport and storage in living organisms [28-30]. One of the first discovered dioxygen activating heme enzymes, cytochrome P-450 [31], has provided many clues about the catalytic cycles of dioxygen activation and oxygen transfer reactions. Design of metal catalysts to mimic bio-oxidative activity of cytochrome P-450 has continued to be an active area of research [32].

Hereafter, we report on the synthesis and characterization of iron (III) and manganese (III) complexes containing $N, N$-bis(1-naphthalidimine)-o phenylenediamine ligand as well as their applications in the catalytic oxidation of cyclohexene by molecular oxygen. The experimental characterization can be correlated and explained with DFT calculation as well as the origin of the electron transfers observed by cyclic voltammetry.

\section{Experimental}




\subsection{Materials and Measurements}

The melting points for the ligand $\mathrm{LH}_{2}$ and its complexes of $\mathrm{LFe}(\mathrm{III}) \mathrm{Cl}$ and $\mathrm{LMn}(\mathrm{III}) \mathrm{Cl}$ were determined with a Kofler Bench 7779 apparatus. Infrared spectra were recorded using $\mathrm{KBr}$ pellets on a Shimadzu FTIR IRAffinity-1 spectrophotometer. Electronic spectra were measured on a Shimadzu UV-1800 double-beam spectrophotometer using DMF as solvent. Elemental analyses were carried out on an Elementar-Vario EL III CHNSO analyser. ${ }^{1} \mathrm{H}$ NMR spectra were recorded on a Bruker Advance $500 \mathrm{MHz}$ spectrometer using DMSO- $\mathrm{d}_{6}$ as solvent and tetramethylsilane (TMS) as internal standard. Mass spectrum of the ligand $\mathrm{LH}_{2}$ is obtained on a Bruker Daltonics Flex Analysis spectrometer with MALDI-TOF procedure using ditranol as matrix. The molar conductivities of the compounds were carried out on conductivity meter MeterLab CDM-210 apparatus.

The electrochemical properties of the structures were investigated at room temperature in DMF solutions containing tetra- $n$-butylammonium perchlorate (TBAP), $0.1 \mathrm{M}$, as supporting electrolyte. A classical three electrodes cell was used with glassy carbon (GC) working electrode (WE), a platinum counter electrode and a saturated calomel electrode (SCE) reference electrode. All potential values are given versus SCE and the ligand and complexes solutions were $10^{-3} \mathrm{M}$ and the scan rate used in all the voltammograms was set to $100 \mathrm{mV} \mathrm{s}^{-1}$.

\subsection{X-ray crystallography}

Single crystals of $\mathrm{LH}_{2}$ ligand were grown by slow evaporation of DMSO solution at room temperature. The crystals were placed in oil and a red prism single crystal of dimensions $0.40 \times 0.38 \times 0.28 \mathrm{~mm}^{3}$ was selected.

X-Ray diffraction data collection was carried out on a Bruker APEX II DUO Kappa-CCD diffractometer equipped with an Oxford Cryosystem liquid $\mathrm{N}_{2}$ device, using Mo-K $\alpha$ radiation $(\lambda=0.71073 \AA)$. The crystal-detector distance was $38 \mathrm{~mm}$. The cell parameters were determined (APEX2 software) [33] from reflections taken from tree sets of 12 frames, each at 10s exposure. The structure was solved by direct methods using the program SHELXS-97 [34]. The refinement and all further calculations were carried out using SHELXL-97 [35]. The H-atoms were included in calculated positions and treated as riding atoms using SHELXL default parameters. The non-H atoms were refined anisotropically, using weighted full-matrix leastsquares on $\mathrm{F}^{2}$. A semi-empirical absorption correction was applied using SADABS in APEX2 [36]; transmission factors: $\mathrm{T}_{\min } / \mathrm{T}_{\max }=2.69 / 28.01$. 


\subsection{Quantum chemical calculations}

The Theoretical calculations were performed using the Gaussian $09 \mathrm{~W}$ program, based on Density Functional Theory (DFT) [37] with Beck's three parameters hybrid functional exchange [38], with 6-31G (d. p) basis sets, and Lee-Yang-Parr correlation functional (B3LYP) $[39,40]$.

\subsection{Hirshfeld surface analysis}

The Hirshfeld Surface (HS) and a 2D fingerprint scatter plots for $\mathrm{LH}_{2}$ were obtained using the Crystal Explorer 17.5 package [41]. The normalized contact distance $\left(d_{\text {norm }}\right)$ based on both $d_{\mathrm{e}}$ and $d_{\mathrm{i}}$ (where $d_{\mathrm{e}}$ is distance from a point on the surface to the nearest nucleus outside the surface and $d_{\mathrm{i}}$ is distance from a point on the surface to the nearest nucleus inside the surface) and the vdW radii of the atom. Graphical plots of the molecular Hirshfeld surfaces mapped with $d_{\text {norm }}$ used a red-white-blue color scheme; where red show shorter contacts, white constitute the contact around vdW separation and blue depict longer contacts.

\subsection{General procedure of the oxidation reaction}

In a typical experiment, $10 \mathrm{mmol}$ of the manganese and iron catalysts were dissolved in $10 \mathrm{~mL}$ of DMF and $10 \mathrm{mmol}$ of cyclohexene in the presence of molecular oxygen $\left(\mathrm{O}_{2}\right)$, the reaction is carried out under bubbling with a needle introduced into the mixture. The reaction mixture was refluxed while being stirred for $6 \mathrm{~h}$.

A blank experiment in the absence of the complex was performed and no oxidation products were observed. In gas chromatography, the retention times for the starting materials and the products were determined by comparison with authentic samples. The conversion percentiles (\%) are calculated by the following equation, in which $\mathrm{C}_{\text {initial }}$ and $\mathrm{C}_{\text {final }}$ are initial and final concentration of the substrate, respectively.

$$
\% \text { Conversion }=100\left(C_{\text {initial }}-C_{\text {final }}\right) / C_{\text {initial }}
$$

\subsection{Synthesis}

\subsubsection{Synthesis of the ligand $\mathrm{LH}_{2}$}

The ligand was prepared by adapting literature methods [42]. A mixture of $0.5 \mathrm{mmol}$ ( $0.054 \mathrm{~g})$ of 1,2-diaminobenzene and $1 \mathrm{mmol}(0.172 \mathrm{~g})$ of 2-hydroxy-1-naphthaldehyde, in 10 $\mathrm{mL}$ of methanol was refluxed with constant stirring under nitrogen atmosphere for $3 \mathrm{~h}$ to yield an abundant orange precipitate that was collected by filtration. The precipitate was washed successively with methanol (3 x $6 \mathrm{~mL})$ and diethyl ether $(3 \times 6 \mathrm{~mL})$, recrystallized from DMSO- 
Ethanol and dried under vacuum overnight. Crystals suitable for X-ray analysis were obtained by slow evaporation of DMSO. The Schiff base ligand was characterized by elemental analysis and spectroscopic methods. Yield: $67 \%$, mp: $221{ }^{\circ} \mathrm{C} . \Lambda\left(\Omega^{-1} \mathrm{~cm}^{2} \mathrm{~mole}^{-1}\right)=11.98$. Analysis calculated: $\mathrm{C}_{28} \mathrm{H}_{20} \mathrm{O}_{2} \mathrm{~N}_{2} .0 .5 \mathrm{MeOH}: \mathrm{C}, 79.15 ; \mathrm{H}, 5.13 ; \mathrm{N}, 6.48 \%$; found: $\mathrm{C}, 78.47 ; \mathrm{H}, 5.14 ; \mathrm{N}$, $6.29 \%$. Selected IR data (KBr pellets, $\left.\sigma \mathrm{cm}^{-1}\right): 3440(\mathrm{O}-\mathrm{H}), 1616(\mathrm{C}=\mathrm{N}), 1537(\mathrm{C}=\mathrm{C}), 1179$ (C-O); UV-Vis: DMF, $\lambda$ nm, [ $\varepsilon \mathrm{M}^{-1} \mathrm{~cm}^{-1}$ ]: 269 [11300], 316 [9650], 350 [8130], 364 [7880], 410 [4580]; ${ }^{1} \mathrm{H}$ NMR (DMSO-d 6 , $\delta$ ppm): 9.69 (s, CH=N), 7.05-8.55 (m, Ar-H); ${ }^{13} \mathrm{C} \mathrm{NMR}$ (DMSO-d 6 , $\delta$ ppm): $157(\mathrm{C}=\mathrm{N}), 169(\mathrm{C}-\mathrm{O}), 100-150(\mathrm{C}-\mathrm{Ar})$; MS (MALDI-TOF, ditranol): $[\mathrm{MH}]^{+}=417.16$.

\subsubsection{Synthesis of the complexes}

\subsubsection{Synthesis of LFe(III)CI}

Title complex were obtained by the general procedure given in the following literature methods [43]. $\mathrm{FeCl}_{2} .4 \mathrm{H}_{2} \mathrm{O} 0.5 \mathrm{mmol}(0.099 \mathrm{~g})$ were dissolved in methanol $5 \mathrm{ml}$ was added to a $5 \mathrm{ml}$ methanol solution containing $\mathrm{LH}_{2} 0.5 \mathrm{mmol}(0.208 \mathrm{~g})$. The mixture was refluxed and stirred for $2 \mathrm{~h}$ under nitrogen atmosphere. A brown compound precipitated out, washed with methanol and diethyl ether, and then recrystallized from DMSO-methanol. Yield: 78\%; mp > $300{ }^{\circ} \mathrm{C} . \Lambda\left(\Omega^{-1} \mathrm{~cm}^{2}\right.$ mole $\left.^{-1}\right)=11.67$. Analysis calculated for $\mathrm{C}_{28} \mathrm{H}_{18} \mathrm{O}_{2} \mathrm{~N}_{2} \mathrm{Fe} \cdot \mathrm{H}_{2} \mathrm{O}: \mathrm{C}, 68.87 ; \mathrm{H}$, 4.13; N, 5.74. Found: C, 68.98; H, 4.30; N, $5.59 \%$; IR (KBr pellets, $\left.\sigma \mathrm{cm}^{-1}\right): 3452(\mathrm{O}-\mathrm{H})$, $1598(\mathrm{C}=\mathrm{N}), 1535(\mathrm{C}=\mathrm{C}), 1187(\mathrm{C}-\mathrm{O})$; UV-Vis: DMF, $\lambda \mathrm{nm},\left[\varepsilon \mathrm{M}^{-1} \mathrm{~cm}^{-1}\right]: 266[3750]$, 341[2770], 409[1790], 476[1240].

\subsubsection{Synthesis of $\mathrm{LMn}(\mathrm{III}) \mathrm{Cl}$}

To a $5 \mathrm{ml}$ methanolic solution of $\mathrm{MnCl}_{2} 0.5 \mathrm{mmol}(0.063 \mathrm{~g}$,), a methanolic solution of the ligand $\mathrm{LH}_{2} 0.5 \mathrm{mmol}(0.208 \mathrm{~g})$ was added dropwise. The mixture was refluxed and stirred for $2 \mathrm{~h}$ under nitrogen atmosphere and then filtered. The precipitate, washed with methanol and diethyl ether, was re-crystallized from DMF-methanol. Yield: $70 \% ; \mathrm{mp}>300{ }^{\circ} \mathrm{C} ; \Lambda\left(\Omega^{-1} \mathrm{~cm}^{2}\right.$ mole $\left.{ }^{-1}\right)=26.41$. Analysis calculated: $\mathrm{C}_{28} \mathrm{H}_{18} \mathrm{~N}_{2} \mathrm{O}_{2} \mathrm{Mn} .0 .5 \mathrm{H}_{2} \mathrm{O}: \mathrm{C}, 70.30 ; \mathrm{H}, 4.00 ; \mathrm{N}, 5.86$. Found: C, 69.79; H, 4.26; N, 5.44 \%; IR (KBr pellets, $\left.\sigma \mathrm{cm}^{-1}\right)$ : $3439(\mathrm{O}-\mathrm{H}), 1607(\mathrm{C}=\mathrm{N}), 1536$ $(\mathrm{C}=\mathrm{C}), 1181(\mathrm{C}-\mathrm{O})$; UV-Vis: DMF, $\lambda \mathrm{nm},\left[\varepsilon \mathrm{M}^{-1} \mathrm{~cm}^{-1}\right.$ ]: 270 [5380], 340 [4350], 412 [2850], 472 [2030]. 


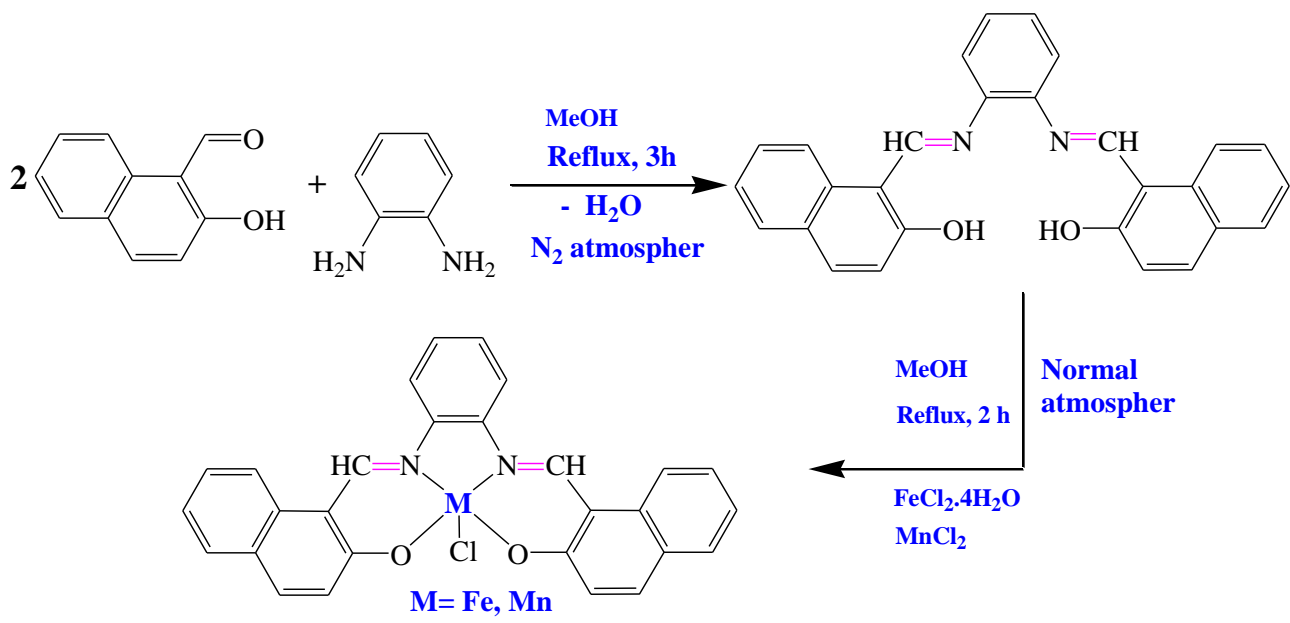

Scheme 1. Synthesis of the ligand $\left(\mathrm{LH}_{2}\right)$ and the corresponding complexes.

\section{Results and discussion}

\subsection{Elemental analysis and molar conductance}

The analytical data are in good agreements with the proposed structures of the Schiff base ligand and their complexes, corroborating the occurrence of a half-molecule of methanol in the $\mathrm{LH}_{2}$ ligand. However, the complexes show a ligand-metal of stoichiometric ratio of 1:1 affording mononuclear compounds with the presence of a molecule of water and a half one for respectively the $\mathrm{LFe}(\mathrm{III}) \mathrm{Cl}$ and $\mathrm{LMn}(\mathrm{III}) \mathrm{Cl}$ complexes.

The observed molar conductance of the ligand and the complexes in DMF $\left(10^{-3} \mathrm{M}\right)$ solution are in the range $11.67-26.41 \Omega^{-1} \mathrm{~cm}^{2} \mathrm{~mol}^{-1}$, the molar conductance values are nonelectrolytic nature for the complexes, the Schiff base ligand is also regarded as a non-electrolyte [44].

\subsection{Infrared Spectra}

The IR spectra of $\mathrm{LH}_{2}$ and their complexes were analyzed in the region $4000-400 \mathrm{~cm}^{-1}$. The spectra of ligand and complexes display IR absorption bands at 1616 and $1594 \mathrm{~cm}^{-1}$, respectively, which are attributed to $\mathrm{C}=\mathrm{N}$ transitions of the azomethine moiety [45]. The shift band of the $\mathrm{LFe}(\mathrm{III}) \mathrm{Cl}$ and $\mathrm{LMn}(\mathrm{III}) \mathrm{Cl}$ complexes towards lower wave number indicates coordination of the imine nitrogen to the metal center [46]. In addition, the stretching vibration of $\mathrm{C}-\mathrm{O}, v_{\mathrm{C}-\mathrm{O} / \text { naphtholate }}$, appears at $1179 \mathrm{~cm}^{-1}$ in the ligand form, whereas in the complexes $\mathrm{LFe}(\mathrm{III}) \mathrm{Cl}$ and $\mathrm{LMn}(\mathrm{III}) \mathrm{Cl}$, it is shifted to higher energy by $20 \mathrm{~cm}^{-1}$ suggesting that the metallic center causes an increase of the electronic density in the vicinity of the oxygen of pristine ligand. This behavior can be interpreted as a result of coordination of both deprotonated oxygen of naphtolic group to the metal center giving $\mathrm{N}_{2} \mathrm{O}_{2}$ tetra-coordinated complexes [47]. The DFT calculations strongly corroborate the experimental results and our hypotheses. 
Table 1. Selected experimental and theoretical infrared frequencies $\left(\mathrm{cm}^{-1}\right)$ and their assignments for $\mathrm{LH}_{2}, \mathrm{LMnCl}$ and $\mathrm{LFeCl}$.

\begin{tabular}{|c|c|c|c|c|c|c|c|c|c|}
\hline \multicolumn{3}{|l|}{$\mathrm{LH}_{2}$} & \multicolumn{3}{|c|}{$\mathrm{LFeCl}$} & \multicolumn{3}{|c|}{$\mathrm{LMnCl}$} & \multirow{3}{*}{ Assignments } \\
\hline \multirow{2}{*}{ Exp } & \multicolumn{2}{|c|}{ Calculated } & \multirow{2}{*}{ Exp } & \multicolumn{2}{|c|}{ Calculated } & \multirow{2}{*}{ Exp } & \multicolumn{2}{|c|}{ Calculated } & \\
\hline & Unscaled & Scaled & & Unscaled & scaled & & Unscaled & scaled & \\
\hline 1616 & 1630 & 1581 & 1598 & 1553 & 1506 & 1607 & 1677 & 1626 & $\mathrm{C}=\mathrm{N}$ \\
\hline 1179 & 1213 & 1176 & 1187 & 1208 & 1151 & 1181 & 1230 & 1145 & $\mathrm{C}-\mathrm{O}$ \\
\hline 1537 & 1526 & 1490 & 1535 & 1534 & 1487 & 1536 & 1590 & 1542 & $\mathrm{C}=\mathrm{C}$ \\
\hline 3440 & 3116 & 3336 & - & - & - & - & - & - & $-\mathrm{OH}$ \\
\hline- & - & - & 493 & 485 & 470 & 556 & 577 & 560 & $\mathrm{M}-\mathrm{N}$ \\
\hline - & - & - & 552 & 551 & 534 & 476 & 445 & 431 & $\mathrm{M}-\mathrm{O}$ \\
\hline
\end{tabular}

\subsection{Electronic absorption spectra}

In the spectrum of the ligand (figure 1), the band located at $460 \mathrm{~nm}$ is assigned to the $\mathrm{n} \rightarrow \pi^{*}$ transition from the azomethine $(\mathrm{CH}=\mathrm{N})$ group [48]. In the spectra of the metal complexes, these $n \rightarrow \pi *$ transitions, are shifted to lower frequencies indicating that the imine nitrogen atoms are involved in coordination to the metal ion. The bands at higher energies 260 and $310 \mathrm{~nm}$ are associated with the aryl $\pi \rightarrow \pi^{*}$ transitions. The spectra of the complexes show tow intense bands in the high-energy, at 345 and $410 \mathrm{~nm}$, attributed to $\mathrm{L} \rightarrow \mathrm{M}$ charge transfer bands (MLCT) [49].

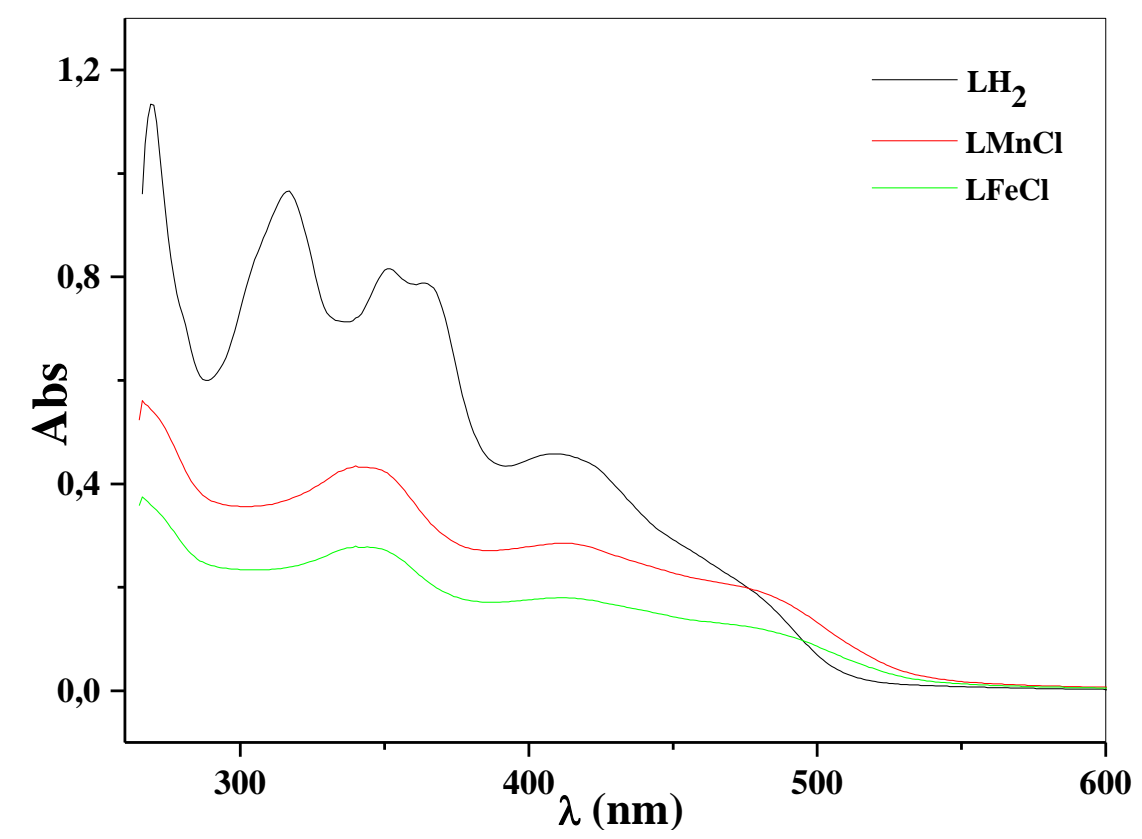

Figure 1. Electronic spectra of the ligand and the corresponding complexes in DMF

\subsection{NMR spectra}

The ${ }^{1} \mathrm{H}$ NMR spectrum of the ligand (figure 2 (a)) exhibits a multiplet in the region 6.60$8.80 \mathrm{ppm}$ assignable to aromatic protons $(\mathrm{CH}-\mathrm{Ar})$ of the benzene and naphthalene ring. The sharp singlet at $9.69 \mathrm{ppm}$ is due to azomethine proton $(\mathrm{CH}=\mathrm{N})$. The phenolic proton is not observed because of the exchange with the water present in the DMSO- $\mathrm{d}_{6}$. 
The ${ }^{13} \mathrm{C}$ NMR spectrum of the ligand is in agreement with the different types of magnetically nonequivalent carbons (figure 2(b)). The resonance around $157 \mathrm{ppm}$ can be assigned to the azomethine carbon $(-\mathrm{C}=\mathrm{N}-$ ). The signal observed at $169 \mathrm{ppm}$ corresponds to the naphtholate $(-\mathrm{C}-\mathrm{O}-)$. The carbon atoms of the benzene and naphthalene ring occurring over a broad range 110-140 ppm.

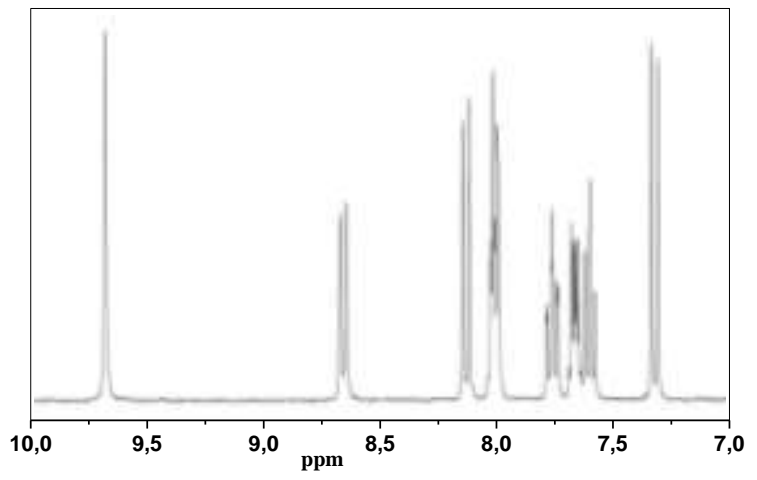

(a)

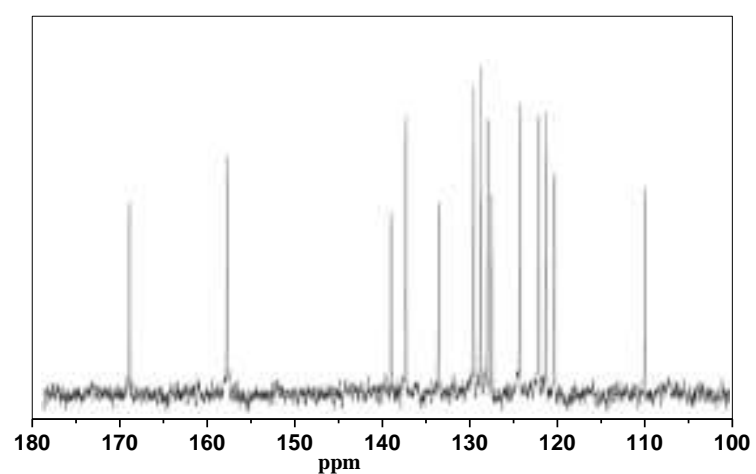

(b)

Figure 2. NMR spectra of $\mathrm{LH}_{2}$ ligand in DMSO-d 6 : (a) ${ }^{1} \mathrm{H} \mathrm{NMR}$, (b) ${ }^{13} \mathrm{C}$ NMR

\subsection{Mass spectrometry}

The mass spectra of the ligand were recorded in MALDI TOF ionization mode (figure 3). The protonated molecular ion peak $[\mathrm{MH}]^{+}$of the ligand appears at $\mathrm{m} / \mathrm{z}=417.16$, which is in good agreement with the proposed formula.

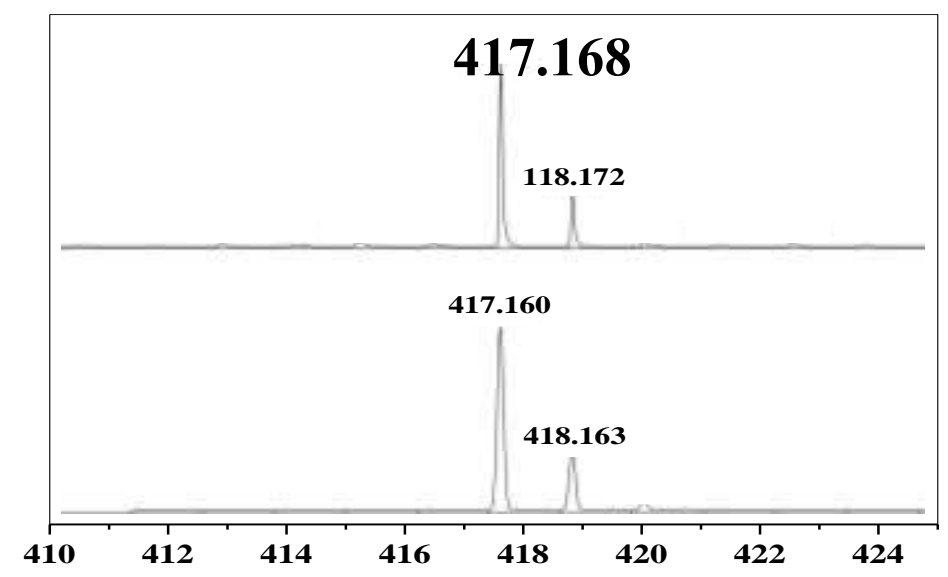

Figure 3. Molecular cluster of the masse spectrum of $\mathrm{LH}_{2}$ ligand, MALDI-TOF in dithranol.

\subsection{Structural data}

The ligand $\mathrm{LH}_{2}$ has been characterized by X-ray diffraction. Its solid state structure matches the optimized theoretical structure obtained by DFT calculation, whereas the molecular structures of $\mathrm{LMn}(\mathrm{III}) \mathrm{Cl}$ and $\mathrm{LFe}(\mathrm{III}) \mathrm{Cl}$ were only obtained by DFT calculations. Figure 4 summarizes the geometry of the ligand and the calculated geometries of the complexes. Table 2 summarizes the crystal data, the data collection and the structure refinement parameters and Figure 5 shows the unit cell of the ligand $\mathrm{LH}_{2}$. 
Table 2. Data collection and structure refinement parameters.

\begin{tabular}{|c|c|}
\hline Compound & $\mathrm{LH}_{2} \cdot \mathrm{DMSO}$ \\
\hline Molecular formula & $\mathrm{C}_{30} \mathrm{H}_{26} \mathrm{~N}_{2} \mathrm{O}_{3} \mathrm{~S}$ \\
\hline Molecular weight (g/mol) & 494.59 \\
\hline Crystal system & Monoclinic \\
\hline Space group & $\mathrm{P} 2{ }_{1} / \mathrm{c}$ \\
\hline$a(\check{\mathrm{A}})$ & $13.353(4)$ \\
\hline$b(\stackrel{\mathrm{A}}{)})$ & $7.561(2)$ \\
\hline$c(\stackrel{\mathrm{A}}{)})$ & $24.350(8)$ \\
\hline$\beta\left(^{\circ}\right)$ & $90.959(10)$ \\
\hline$V\left(\breve{A}^{3}\right)$ & 2458.43(13) \\
\hline $\mathrm{Z}$ & 4 \\
\hline$D_{\text {calc }}\left(\right.$ g.cm $\left.{ }^{-3}\right)$ & 1.336 \\
\hline Crystal size $\left(\mathrm{mm}^{3}\right)$ & $0.40 \times 0.38 \times 0.28$ \\
\hline Crystal description & Prism \\
\hline Crystal color & Red \\
\hline Temperature (K) & $173(2)$ \\
\hline Radiation Mo-K $\alpha 1$ & $\lambda=0.71073 \AA$ \\
\hline Absorption coefficient $\left(\mathrm{mm}^{-1}\right)$ & 0.168 \\
\hline$F(000)$ & 1040 \\
\hline Reflections collected/unique & $17304 / 5917$ \\
\hline $\mathrm{R}_{\text {int }}$ & 0.0173 \\
\hline Range/indices $(h, k, l)$ & $-16 \rightarrow 17 ;-9 \rightarrow 9 ;-32 \rightarrow 32$ \\
\hline Teta $_{\text {limit }}$ & $1.53 \rightarrow 28.01$ \\
\hline No. of observed data & 4939 \\
\hline $\begin{array}{l}I>2 \operatorname{Sigma}(I) \\
\text { No. of variables }\end{array}$ & 328 \\
\hline No. of restraints & 0 \\
\hline Goodness of fit on $F^{2}$ & 1.032 \\
\hline$R_{1}, w R_{2}[I \geq 2 \operatorname{Sigma}(I)]^{\mathrm{a}}$ & $0.434,0.1090$ \\
\hline$R_{1}, w R_{2}$ (all data) $^{\mathrm{a}}$ & $0.0543,0.1196$ \\
\hline
\end{tabular}

The XRD analysis proves that the asymmetric unit of $\mathrm{LH}_{2}$ ligand (Figure $4 \mathrm{a}$ ) is very far from a planar geometry; the two naphthalene moieties and the single aryl belong to three different plans, as shown in Figure $4 \mathrm{~b}$. The angles between the plans are $28.57^{\circ}, 39.02^{\circ}$ and $41.83^{\circ}$, but the molecule of $\mathrm{LMn}(\mathrm{III}) \mathrm{Cl}$ (Figure 4c) is less distorted. Figure $4 \mathrm{~d}$ shows that the angles between the plans are $14.92^{\circ}, 27.76^{\circ}$ and $42.60^{\circ}$ in the case of the $\mathrm{LMn}(\mathrm{III}) \mathrm{Cl}$ complex, a strikingly different situation than in the LFe(III)Cl complex (Figure 3e) in which planarity with an out of the plane positioning of the Fe is observed (Figure 4f).
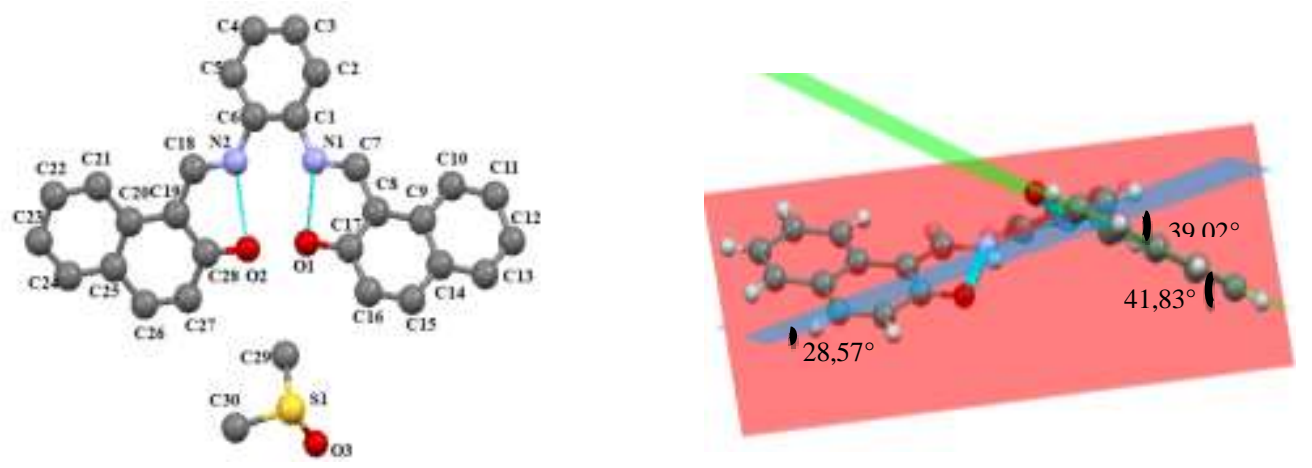

(b) 


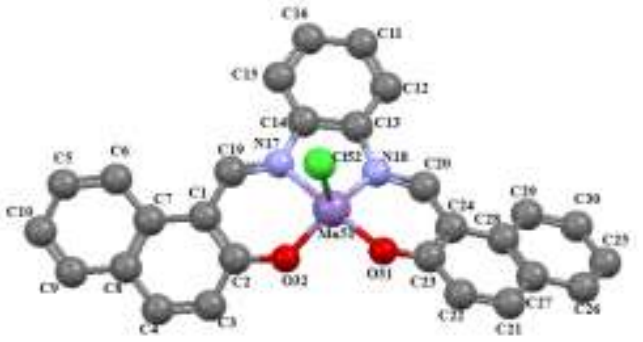

(c)

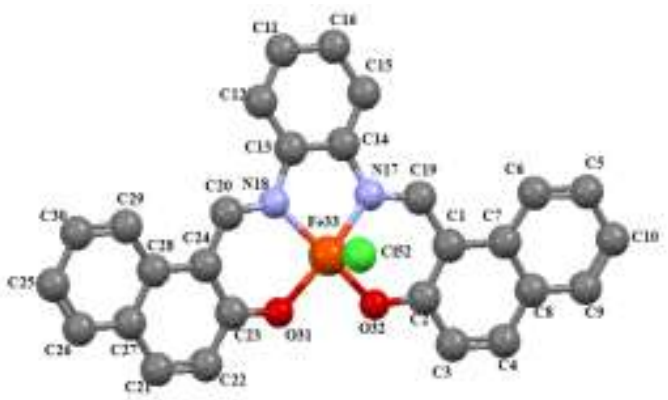

(e)

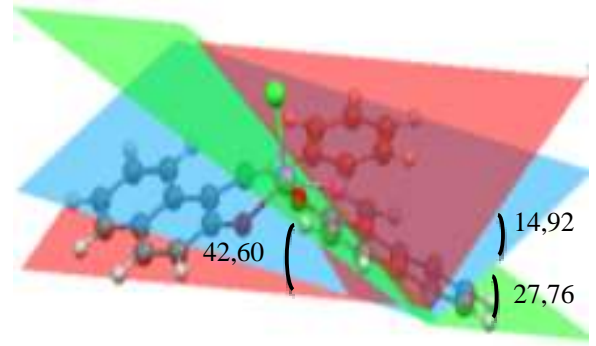

(d)

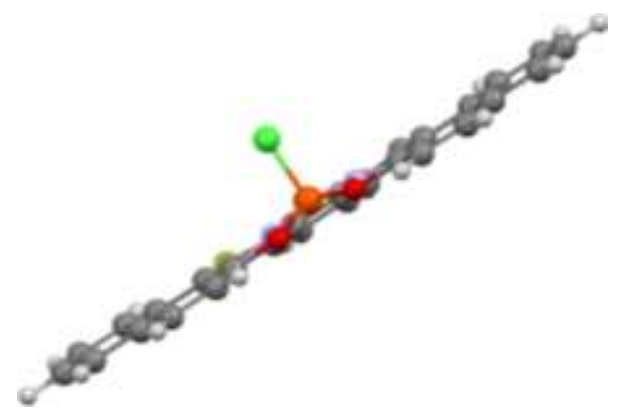

(f)

Carbon Sulfure Oxygen $\bullet$ Hydrogen Nitrogen $\odot$ Chlorine $\odot$ Manganese $\odot$ Iron

Figure 4. Molecular structures (a) asymmetric unit of the ligand $\mathrm{LH}_{2}$ provided by hydrogen bonds (b) optimized structure of LMn(III)Cl (c) optimized structure of LFe(III)Cl.

Some characteristic bond distances and angles are listed in Table 3.

Table 3. Selected experimental and theoretical bond lengths $(\AA)$ and angles values $\left(^{\circ}\right)$.

\begin{tabular}{lllllll}
\hline $\mathrm{LH}_{2}$ & & & LMn(III)Cl & LFe(III)Cl & \\
\hline Selected bonds & X-ray $(\AA)$ & Calc. $(\AA)$ & Selected bonds & Calc. $(\AA)$ & Selected bonds & Calc. $(\AA)$ \\
\hline $\mathrm{C} 1-\mathrm{N} 1$ & $1.410(17)$ & 1.410 & Mn-O1 & 1.858 & Fe-O1 & 1.873 \\
$\mathrm{C} 6-\mathrm{N} 2$ & $1.409(17)$ & 1.410 & Mn-O2 & 1.826 & Fe-O2 & 1.873 \\
$\mathrm{C} 7-\mathrm{N} 1$ & $1.298(17)$ & 1.298 & $\mathrm{Mn}-\mathrm{N} 1$ & 1.898 & $\mathrm{Fe}-\mathrm{N} 1$ & 1.922 \\
$\mathrm{C} 17-\mathrm{O} 1$ & $1.327(18)$ & 1.328 & $\mathrm{Mn}-\mathrm{N} 2$ & 2.042 & $\mathrm{Fe}-\mathrm{N} 2$ & 1.922 \\
$\mathrm{C} 18-\mathrm{N} 2$ & $1.311(17)$ & 1.311 & $\mathrm{Mn}-\mathrm{Cl}$ & 2.208 & $\mathrm{Fe}-\mathrm{Cl}$ & 2.284 \\
$\mathrm{C} 28-\mathrm{O} 2$ & $1.290(18)$ & 1.291 & O1-C17 & 1.291 & O1-C17 & 1.320 \\
& & & O2-C28 & 1.320 & O2-C28 & 1.320 \\
& & & N1_C7 & 1333 & N1_C7 & 1320 \\
\hline Selected angles & X-ray $\left({ }^{\circ}\right)$ & Calc. $\left({ }^{\circ}\right)$ & Selected angles & Calc. $\left({ }^{\circ}\right)$ & Selected angles & Calc. $\left({ }^{\circ}\right)$ \\
\hline
\end{tabular}




\begin{tabular}{lllllll}
\hline C2-C1-N1 & $122.70(12)$ & 122.66 & O2-Mn-O1 & 94.20 & O2-Fe-O1 & 87.78 \\
C6-C1-N1 & $120.00(13)$ & 117.52 & O1-Mn-N1 & 94.15 & O1-Fe-N1 & 91.35 \\
C5-C6-N2 & $122.26(13)$ & 122.26 & O1-Mn-N2 & 172.22 & O2-Fe-N1 & 163.73 \\
C1-C6-N2 & $117.69(12)$ & 117.69 & O2-Mn-N1 & 132.89 & O1-Fe-N2 & 163.75 \\
N1-C7-C8 & $121.31(13)$ & 121.31 & N1-Mn-N2 & 80.16 & N1-Fe-N2 & 84.93 \\
O1-C17-C8 & $122.53(13)$ & 122.53 & O2-Mn-N2 & 85.95 & O2-Fe-N2 & 91.35 \\
O1-C17-C16 & $117.18(13)$ & 117.18 & N1-Mn-Cl & 107.58 & N1-Fe-Cl & 94.74 \\
N2-C18-C19 & $122.15(13)$ & 122.15 & N2-Mn-Cl & 87.19 & N2-Fe-Cl & 94.73 \\
\hline
\end{tabular}

The $\mathrm{LH}_{2}$ unit cell is shown in the figure 5. The crystal is monoclinic with $\mathrm{P} 21 / \mathrm{c}$ space group and the cell parameters are $\mathrm{a}=13.353(4) \AA, \mathrm{b}=7.561(2) \AA, \mathrm{c}=24.350(8) \AA$ and $\beta=$ $90.959(10)^{\circ}$. The filling rate of the $\mathrm{LH}_{2}$ unit cell is about four molecules $(\mathrm{Z}=4)$, the unit cell is characterized by ( $\left.\begin{array}{l}\mathrm{x} y \mathrm{z}\end{array}\right)$ identity, an inversion center at the point $\left(\begin{array}{lll}0 & 0 & 0\end{array}\right)$, a glide plane perpendicular to direction [ $\left[\begin{array}{lll}0 & 1 & 0\end{array}\right]$ with glide component $\left[\begin{array}{lll}0 & 0 & 1 / 2\end{array}\right]$ and finally 2 -fold screw axis with the direction $\left[\begin{array}{lll}0 & 1 & 0\end{array}\right]$ at the points $\left(\begin{array}{lll}0 & 1 / 4\end{array}\right)$ with screw component $\left[\begin{array}{lll}0 & 1 / 2 & 0\end{array}\right]$.

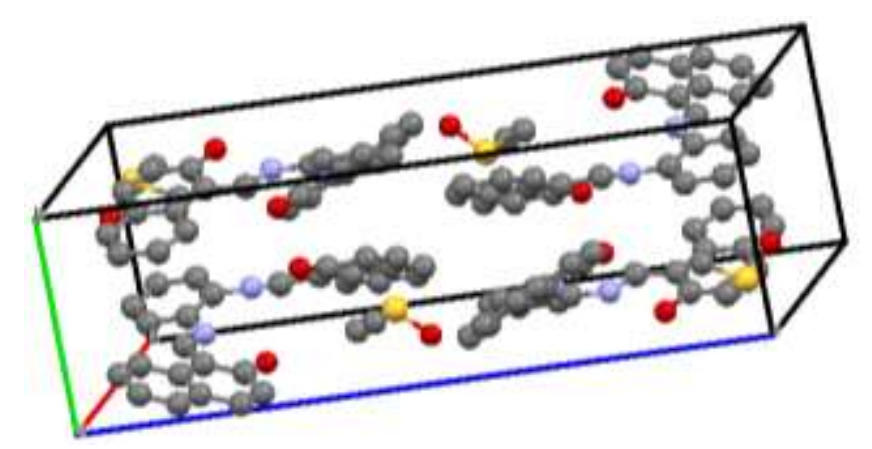

Figure 5. Unit cell of the ligand $\mathrm{LH}_{2}$.

\subsection{Hirshfeld surface analysis}

The Hirshfeld Surface (HS) demonstrates the intermolecular interactions in the crystalline structures. The Figure 6 shows the HS of the ligand $\mathrm{LH}_{2}$ mapped over the ranges: $d_{\text {norm }}[-0.1792$, 1.2866] $\AA$, shape index [-1.0, 1.0] $\mathrm{A}$ and curvedness [-4.0, 0.4] $\mathrm{\AA}$.

The red spots correspond to the closer $\mathrm{O} \cdots \mathrm{H} / \mathrm{H} \cdots \mathrm{O}$ contacts due to the $\mathrm{N}-\mathrm{H} \cdots \mathrm{O}$ hydrogen bonds. The white areas mark the places where the distance between the neighbouring atoms is close to the sum of the Van der Waals radii of the considered atoms, they indicate $\mathrm{H}^{\cdots} \mathrm{H}$ interactions. The blue areas illustrate the domain where the neighbouring atoms are farthest apart to interact with each other (figure 6 (a)). 


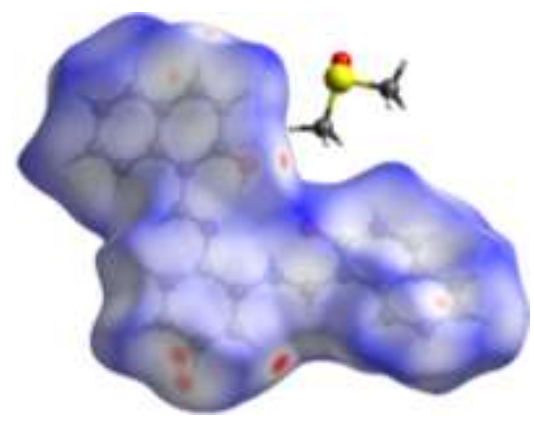

(a)

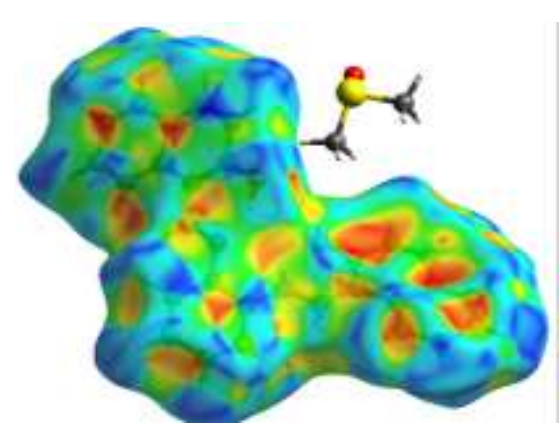

(b)

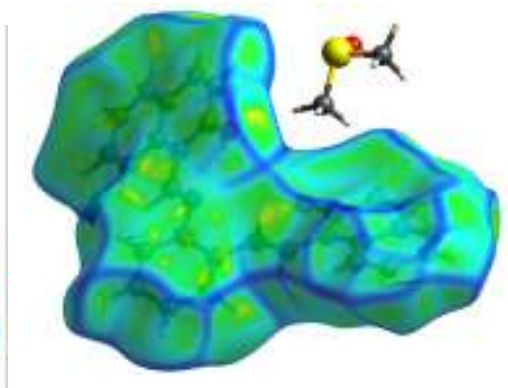

(c)

Figure 6. Hirshfeld surfaces mapped with (a) $d_{\text {norm, }}$ (b) shape index and (c) curvedness of $\mathrm{LH}_{2}$.

Figure 7a illustrates the 2D fingerprint of the totality contacts contributing to the HS of the $\mathrm{LH}_{2}$ ligand. The graph shown in figure $6 \mathrm{~b}$ represent the $\mathrm{H} \cdots \mathrm{O} / \mathrm{O} \cdots \mathrm{H}$ contacts between the hydrogen atoms located inside the HS and the oxygen atoms located at the external and reciprocal. It is characterized by two symmetrical points situated at the top and left and at the bottom right in the region $1.07 \AA<\left(d_{e}+d_{i}\right)<2.57 \AA$, these $\mathrm{O} \cdots \mathrm{H}$ contacts represent $13.3 \%$ of all the intermolecular contacts.

The graph shown in Figure 7c illustrates the 2D fingerprint associated with the hydrogen atoms $\left(\mathrm{r}_{\mathrm{vdW}}=1.20 \AA\right)$. It is characterized by extremity that points to the origin diagonally and corresponding to $d_{i} \approx d_{e} \approx 1.2 \AA$, which reveals the presence of closer $\mathrm{H} \cdots \mathrm{H}$ contacts within the $\mathrm{LH}_{2}$ crystal. They have the largest contribution to the total HS (45.9\%). The decomposition of the 2D fingerprint also shows other contacts: $\mathrm{C} \cdots \mathrm{H}(24.9 \%$, Figure $7 \mathrm{~d}), \mathrm{C}-\mathrm{N}(2.07 \%), \mathrm{C}-\mathrm{O}$ $(0.4 \%), \mathrm{C}-\mathrm{S}(0.2 \%), \mathrm{H}-\mathrm{S}(0.9 \%)$ and $\mathrm{H}-\mathrm{N}(0.3 \%)$.
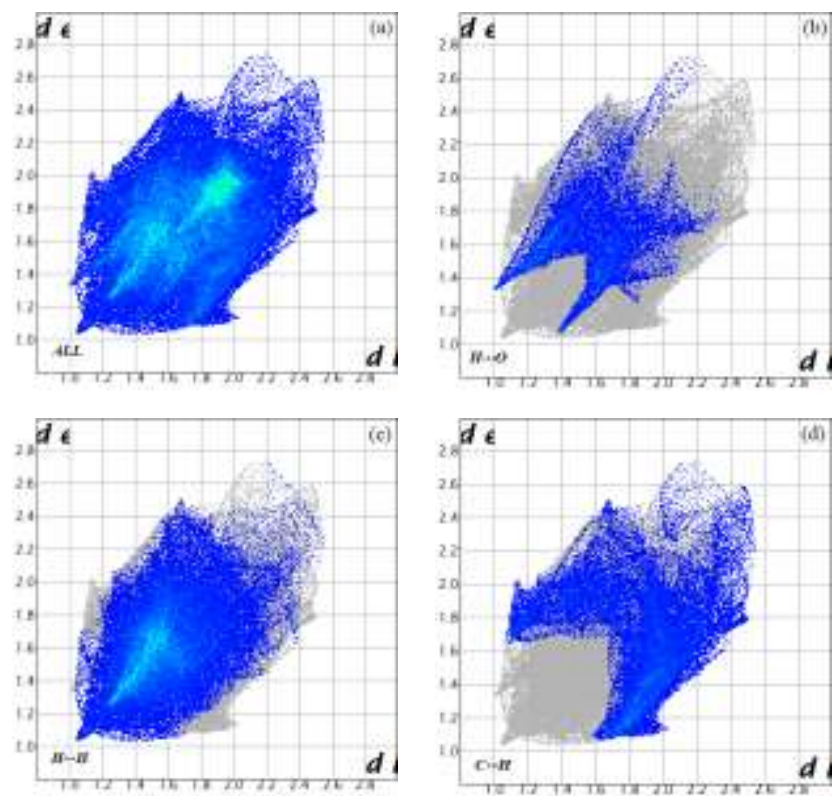
Figure 7. (a) Fingerprint plots Full contact, (b) resolved into $\mathrm{O} \cdots \mathrm{H}$, (c) resolved into $\mathrm{H} \cdots \mathrm{H}$ and (d) resolved $\mathrm{C} \cdots \mathrm{H}$ for the ligand $\mathrm{LH}_{2}$.

\subsection{Experimental hydrogen bonds}

The hydroxyl groups are involved in intramolecular $\mathrm{O}-\mathrm{H}^{\cdots} \mathrm{N}$ hydrogen bonds influencing the molecular conformations. The amino hydrogen atom forms the center of intramolecular hydrogen bonds, which includes the $\mathrm{N}-\mathrm{H} \cdots \mathrm{O}$ hydrogen bond of 2.5499 (16) $\AA$ within the ketoamino part. The proton transfer from the hydroxyl oxygen atom of the parent aromatic aldehyde to the imino nitrogen atom requests a small amount of energy, this proton transfer causes a remarkable conformation changes within the molecule, especially in the $\pi$ electron distribution [50].

Table 4 summarizes the intramolecular hydrogen bonds with corresponding donors and acceptors angles and bond lengths.

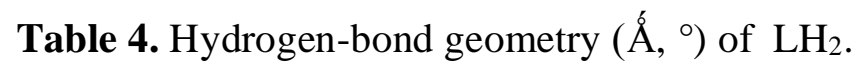

\begin{tabular}{lllll}
\hline $\mathrm{D}-\mathrm{H} \cdots \mathrm{A}$ & $\mathrm{D}-\mathrm{H}$ & $\mathrm{H} \cdots \mathrm{A}$ & $\mathrm{D} \cdots \mathrm{A}$ & $\mathrm{D}-\mathrm{H} \cdots \mathrm{A}$ \\
\hline $\mathrm{N}_{2}-\mathrm{H}_{2} \mathrm{~N} \cdots \mathrm{O}_{2}$ & 0.88 & 1.84 & $2.5499(16)$ & 135.7 \\
\hline $\mathrm{O} 1-\mathrm{H} 1 \cdots \mathrm{N} 1$ & 0.84 & 1.79 & $2.5384(16)$ & 147.6 \\
\hline
\end{tabular}

The planarity within the naphthaldimine part of the molecule is preserved since the pseudoaromatic six membered chilate rings formed by intramolecular hydrogen bonds $\left(\mathrm{H} 1 O^{-}{ }^{-} 1^{-}{ }^{-} 17^{-}{ }^{-} 8^{-}{ }^{-} 7^{-} \mathrm{N} 1\right.$ and $\left.\mathrm{O}^{-}{ }^{-} \mathrm{C} 28^{-}{ }^{-} 19^{-} \mathrm{C} 18^{-} \mathrm{N} 2-\mathrm{H} 2 \mathrm{~N}\right)$ are almost coplanar with corresponding naphthalene rings ( $\mathrm{C} 17$ to $\mathrm{C} 8$ and $\mathrm{C} 28$ to $\mathrm{C} 18)$. The twisting of the naphthaldimine moiety toward the phenyl ring is described by torsion angles $\mathrm{C}^{-}{ }^{-}{ }^{-}{ }^{-}{ }^{-} 1^{-} \mathrm{C} 6$

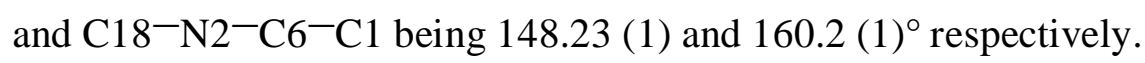

\section{D network}

The structure of the 3D network of $\mathrm{LH}_{2}$ ligand is enriched by weak contacts maintaining the stability and the structural cohesion. Figure 8 shows the 3D network in the views (a) along the $b$ axis (b) according to the $a, b$ plan (c) along the $c$ axis. Along the $b$ axis, $\mathrm{LH}_{2}$ molecules form chains in which they are attached by $\mathrm{H}^{\cdots} \mathrm{H}$ and $\mathrm{C} \cdots \mathrm{H}$ contacts. In addition, the DMSO molecules play a crucial role in the chain as shown in Figure 8b. The contact between $\mathrm{LH}_{2}$ and DMSO molecules is maintained via $\mathrm{O} \cdots \mathrm{H}$ and $\mathrm{C} \cdots \mathrm{H}$ links, along the $c$ axis the contact $\mathrm{C} \cdots \mathrm{C}$ makes the molecules parallel with a distance $7.562 \AA$, (figure 8 (c)). 


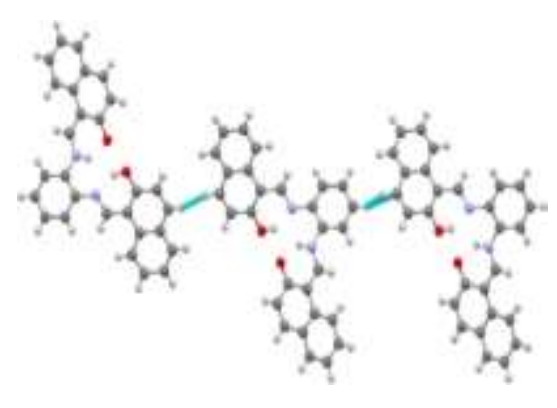

(a): Along b

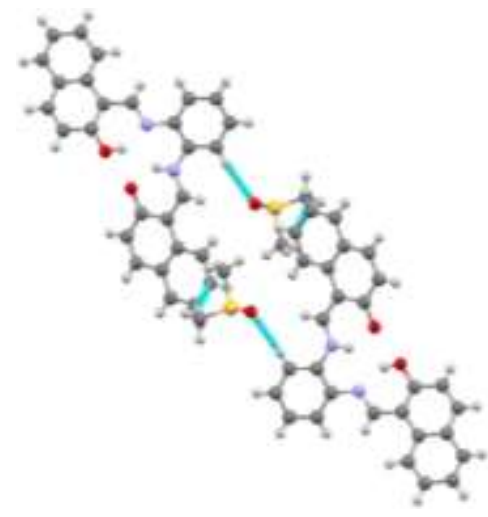

(b): Plan b,a

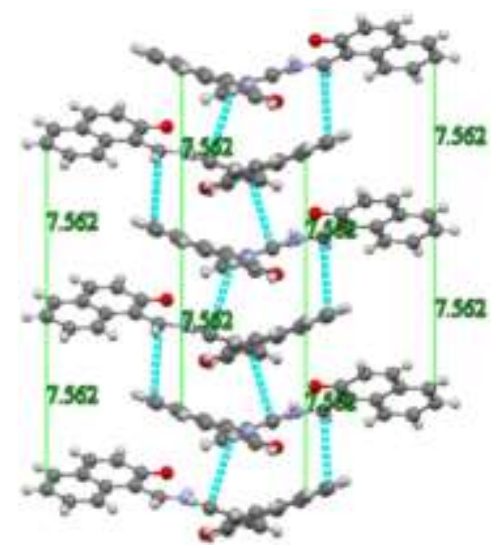

(c): Along c

Figure 8. 3D network in the views (a) along the $b$ axis (b) according to the $b, a$ plan (c) along the $c$ axis.

\section{Quantum calculations results}

\subsection{Molecular Electrostatic Potential (MEP)}

The total electron density surfaces mapped with electrostatic potential for $\mathrm{LH}_{2}, \mathrm{LFe}(\mathrm{III}) \mathrm{Cl}$ and $\mathrm{LMn}(\mathrm{III}) \mathrm{Cl}$ are shown in Figure 9, the surface of $\mathrm{LH}_{2}$ exhibits a positive potential in the most geometric zones, and the most negative potential indicated by a red color is principally centered on the oxygen atoms, those sites can host nucleophilic ions as transition metal ions, a weak negative potential around the cycle indicated by a yellow color can be observed.

Furthermore, the surfaces of $\mathrm{LMn}(\mathrm{III}) \mathrm{Cl}$ and $\mathrm{LFe}(\mathrm{III}) \mathrm{Cl}$ are very comparable. The $\mathrm{Fe}(\mathrm{III})$ and $\mathrm{Mn}(\mathrm{III})$ are coordinated to the oxygen and nitrogen atoms, whereas the apical chlorine bears a strong negative charge indicated by a red color, the comparison with the ligand surface, the potentials generated by the cycle are more positive for the both complex molecules. The nonhomogeneity of the potential distributions for the three molecules results in different values of the dipolar moment 2.644, 5.471 and 5.796 Debye for $\mathrm{LH}_{2}, \mathrm{LMn}(\mathrm{III}) \mathrm{Cl}$ and $\mathrm{LFe}(\mathrm{III}) \mathrm{Cl}$ respectively.
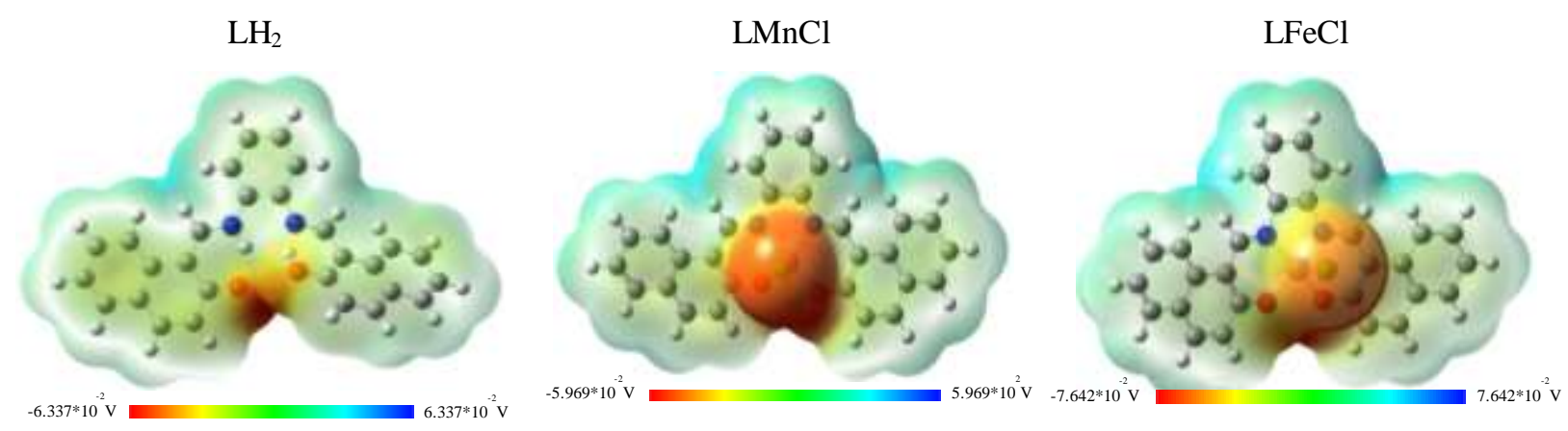

Figure 9. Total electron density map with electrostatic potential of $\mathrm{LH}_{2}, \mathrm{LMnCl}$ and $\mathrm{LFeCl}$.

\subsection{Molecular Orbitals (MOs)}


The molecular orbitals and their relative energies give an important idea on electronic properties and chemical reactions [51]. The figure 10 shows the calculated orbitals for $\mathrm{LH}_{2}$, $\mathrm{LMnCl}, \mathrm{LFeCl}-\alpha$ channel and $\mathrm{LFeCl}-\beta$ channel. It can be seen that all electrons of various molecular orbitals are almost delocalized on the whole molecular structure except for hydrogen atoms.

The gap energy is defined as the energy difference between the HOMO and LUMO. The calculated energies are 3.17, 2.965, 2.861 and $3.094 \mathrm{eV}$, for $\mathrm{LH}_{2}, \mathrm{LMnCl}, \mathrm{LFeCl}-\alpha$ channel and LFeCl- $\beta$ channel respectively, these high values indicate that the molecules are stable. Other characteristic physicochemical parameters are summarized in Table 5.
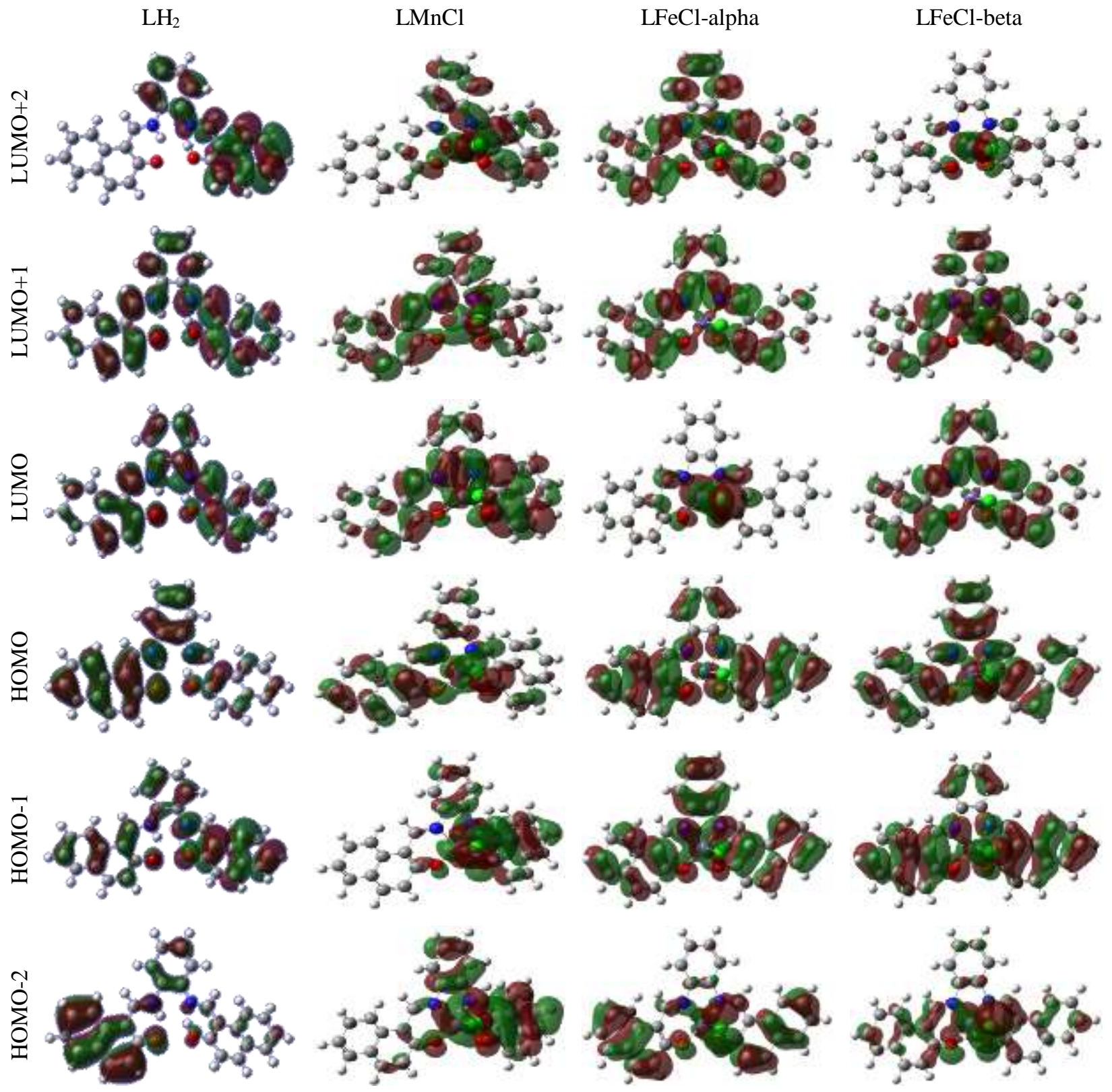

Figure 10. Frontiers Molecular Orbitals plots. 
Table5. Calculated HOMO and LUMO energies and some related physicochemical parameters.

\begin{tabular}{lcccc}
\hline \multicolumn{1}{c}{ Compound } & $\mathrm{LH}_{2}$ & LMnCl & LFeCl- $\alpha$ & LFeCl- \\
\hline & Electronic band energies \\
\hline $\mathrm{E}_{\text {HOMO }}(\mathrm{eV})$ & -5.200 & -5.265 & -5.952 & -5.756 \\
\hline $\mathrm{E}_{\text {HOMO-1 }}(\mathrm{eV})$ & -5.675 & -5.693 & -5.962 & -6.169 \\
\hline $\mathrm{E}_{\mathrm{HOMO}-2}(\mathrm{eV})$ & -6.092 & -5.856 & -6.469 & -6.442 \\
\hline $\mathrm{E}_{\mathrm{LUMO}}(\mathrm{eV})$ & -2.030 & -2.300 & -3.091 & -2.662 \\
\hline $\mathrm{E}_{\mathrm{LUMO}+1}(\mathrm{eV})$ & -1.737 & -2.174 & -2.648 & -2.507 \\
\hline $\mathrm{E}_{\mathrm{LuMO}+2}(\mathrm{eV})$ & -0.658 & -1.906 & -2.295 & -2.252 \\
\hline Energy gap $(\Delta)(\mathrm{eV})$ & 3.17 & 2.965 & 2.861 & 3.094 \\
\hline \multicolumn{5}{c}{ Electrochemical parameters } \\
\hline Dipolar moment $(\mathrm{Debye})$ & 2.644 & 5.471 & 5.796 & 5.796 \\
\hline Ionization potential $(\mathrm{I})$ & 5.20 & 5.265 & 5.952 & 5.756 \\
\hline Electron affinity $(\mathrm{A})$ & 2.03 & 2.30 & 3.091 & 2.662 \\
\hline Global hardness $(\eta)$ & 1.585 & 1.452 & 1.430 & 1.547 \\
\hline Global softness $(\sigma)$ & 0.631 & 0.688 & 0.699 & 0.646 \\
\hline Electronegativity $(\chi)$ & 3.615 & 3.782 & 4.521 & 4.209 \\
\hline Global electrophilicity $(\omega)$ & 3.491 & 4.925 & 7.146 & 5.725 \\
\hline Chemical potential $(\mu)$ & -0.069 & -0.066 & -0.055 & -0.059 \\
\hline
\end{tabular}

$\mathrm{I}=-\mathrm{E}_{\text {номо }}, \mathrm{A}=-\mathrm{E}_{\mathrm{LUMO}}, \chi=-\left[1 / 2\left(\mathrm{E}_{\mathrm{LUMO}}+\mathrm{E}_{\text {Hомо }}\right)\right], \eta=1 / 2\left(\mathrm{E}_{\mathrm{LUMO}}-\mathrm{E}_{\text {номо }}\right), \omega=\chi^{2} /$

$2 \eta . \sigma=1 / \eta, \mu=-1 / 2(\mathrm{~A}+\mathrm{I})$.

\section{Electrochemical Study}

The electrochemical measurements have been carried out, for the ligand $\mathrm{LH}_{2}$ and the complexes $\mathrm{LFe}(\mathrm{III}) \mathrm{Cl}$ and $\mathrm{LMn}(\mathrm{III}) \mathrm{Cl}$, in DMF solution, for their high solubility, under nitrogen saturated atmosphere in the potential range 1600 to $-2200 \mathrm{mV} / \mathrm{SCE}$ at scan rate 100 $\mathrm{mV} / \mathrm{s}$. The $\mathrm{Fc}^{+} / \mathrm{Fc}$, redox couple of ferrocene, was used as an internal standard.

The cyclic voltammogram of the ligand shows irreversible anodic and cathodic peaks (figure 11), appearing at $\mathrm{E}_{\mathrm{pa} 1}=-1.6, \mathrm{E}_{\mathrm{pa} 2}=0.9, \mathrm{E}_{\mathrm{pa} 3}=1.2 \mathrm{~V} / \mathrm{SCE}$ and at $\mathrm{E}_{\mathrm{pc} 1}=-1.5, \mathrm{E}_{\mathrm{pc} 2}=-1.7$ V/SCE respectively. These irreversible waves are attributed to the oxidation of the $\pi$ bonds of the naphtholate moiety and the benzene ring.

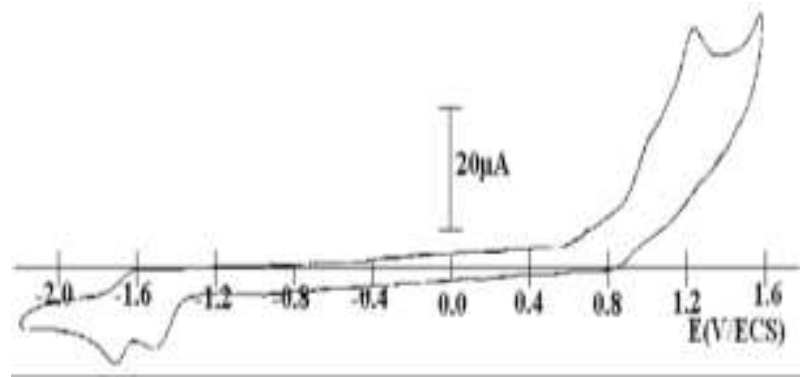

Figure 11. Cyclic voltammogram of $\mathrm{LH}_{2}$ in $0.1 \mathrm{M} \mathrm{TBAP} / \mathrm{DMF}$ at $100 \mathrm{mV} / \mathrm{s}$

The voltammetric study of $\mathrm{LFe}(\mathrm{III}) \mathrm{Cl}$ complex, in the range 100 to $-500 \mathrm{mV} / \mathrm{SCE}$, shows a reversible redox couple at $\mathrm{E}_{1 / 2}=-320 \mathrm{mV} / \mathrm{SCE}$, assignable to the $\mathrm{Fe} \mathrm{III}^{\mathrm{II}} \mathrm{Fe}^{\mathrm{II}}$ couple [52]. Figure 12a shows multiple scans that resulted in superposable cyclic voltammograms of the redox couple. Minimal variation is observed for the potential $E_{p}$ when the scanning speed increases, 
which is characteristic of a reversible system. A linear relationship is observed between the cathodic and the anodic peak currents and the square root of the scanning speed $\left(\mathrm{v}^{1 / 2}\right)$ in the range 10 to $100 \mathrm{mV} / \mathrm{s}$ (Figure $12(\mathrm{c}))$. The value $\Delta \mathrm{E}_{\mathrm{p}}=\left(\mathrm{E}_{\mathrm{pa}}-\mathrm{E}_{\mathrm{pc}}\right)$ is $80 \mathrm{mV} / \mathrm{SCE}$ and the intensity ratio $\mathrm{i}_{\mathrm{pa}} / \mathrm{i}_{\mathrm{pc}}$ is 0.83 , these values reveal a reversible redox process, a typical behavior for an electron transfer process controlled by diffusion.

The cyclic voltammetric studies of LMn(III)Cl complex exhibit a reversible redox couple at $\mathrm{E}_{1 / 2}=-115 \mathrm{mV} / \mathrm{SCE}$ corresponding to $\mathrm{Mn}^{\mathrm{III}} / \mathrm{Mn}^{\mathrm{II}}$ [53]. These results are consistent with a reversible one-electron reduction of the $\mathrm{LMn}(\mathrm{III}) \mathrm{Cl}$ complex (Figure 12b). The variation of peak current parameters as a function of scan rate is plotted in Figure 12c. This is slightly smaller than the corresponding value for the one-electron reduction in $\mathrm{LMn}(\mathrm{III}) \mathrm{Cl}$ complex.

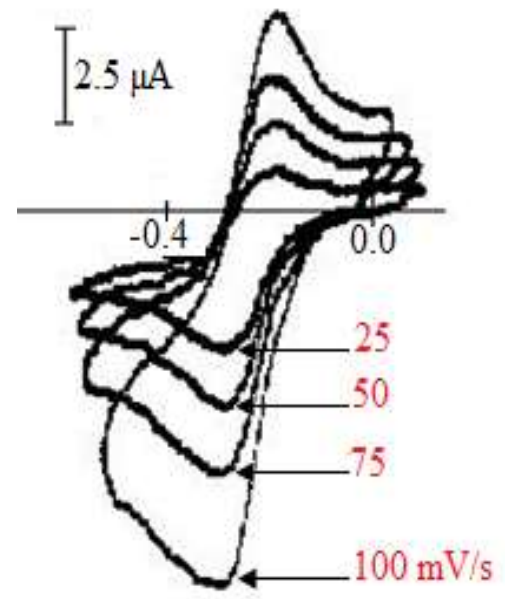

(a)

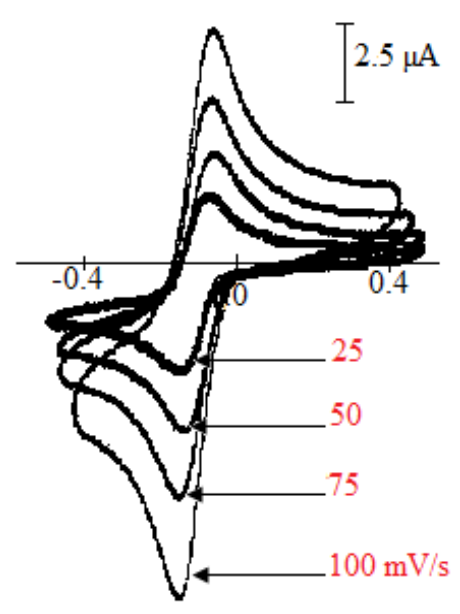

(b)

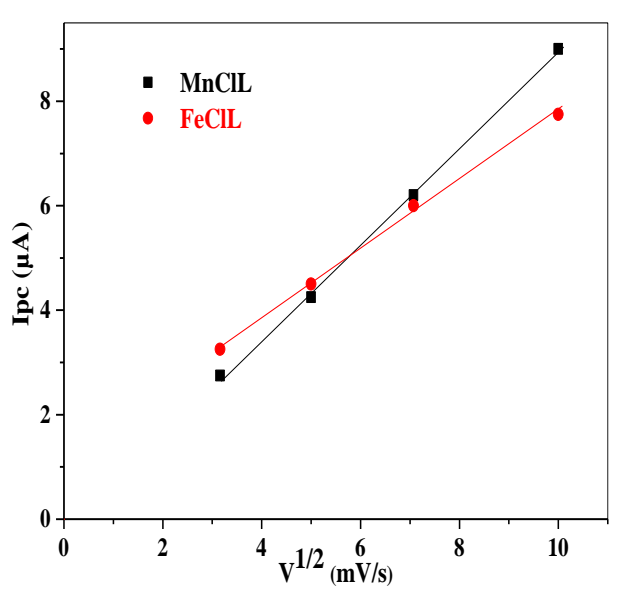

(c)

Figure 12. Cyclic voltammograms in DMF/0.1 M TBAP of $\left(10^{-3} \mathrm{M}\right)(\mathrm{a})$ : $\mathrm{LFe}(\mathrm{III}) \mathrm{Cl},(\mathrm{b})$ : $\mathrm{LMn}(\mathrm{III}) \mathrm{Cl}$. (c): Plot of cathodic currents vs. the square root of sweep rate $\left(\mathrm{v}^{1 / 2}\right)$.

The electrochemical responses of the two $\mathrm{LFe}(\mathrm{III}) \mathrm{Cl}$ and $\mathrm{LMn}(\mathrm{III}) \mathrm{Cl}$ complexes are almost identical which indicate that the electroactive species, in DMF, for the iron and the manganese complexes have probably the same redox character. It is mentioned that a similar process in $\mathrm{Fe}(\mathrm{III}) / \mathrm{Fe}$ (II) has been observed in the iron (III) mononuclear compounds derived from the related Schiff base ligand [54].

Furthermore, the DFT calculation can predict the reduction and oxidation potentials, since the first reduction and oxidation occurs at the HOMO and LUMO and the other oxidation reduction occurs at the other molecular orbitals, generally, a correlation between cyclic voltammetry waves and frontier orbitals energies can be established. The HOMO and LUMO energies of the ligand $\mathrm{LH}_{2}$ and both complexes $\mathrm{LFe}(\mathrm{III}) \mathrm{Cl}$ and $\mathrm{LMn}(\mathrm{III}) \mathrm{Cl}$ can be calculated 
using the oxidation and reduction waves respectively following the empirical relations $\mathrm{E}_{\mathrm{HOMO}}$ $=-\left[\mathrm{E}_{\text {oxydation }}-\mathrm{E}_{1 / 2 \text { (ferrocene) }}+4.8\right] \mathrm{eV}$ and $\mathrm{E}_{\mathrm{LUMO}}=-\left[\mathrm{E}_{\text {reduction }}-\mathrm{E}_{1 / 2 \text { (ferrocene) }}+4.8\right] \mathrm{eV}$.

For the ligand, all oxidation and reduction peaks correspond to the removing or addition of electrons from or to the conjugated $\pi$ system, the potentials are summarized in Table 6 , which illustrate that the waves affect the first and the second levels of FMOs. The first oxidation/reduction affects mostly the orbitals around the naphthalene moieties and the second affects the orbitals around the benzene rings in Figure 10. The comparison of experimental and theoretical values of oxidation and reduction potentials is illustrated in Table 6. Moreover, the experimental and theoretical gap are 2.4, 2.9 and 3.17, 3.94 respectively.

In the $\mathrm{LFe}(\mathrm{III}) \mathrm{Cl}$ complex, the redox couple observed at $\mathrm{E}_{1 / 2}=-0.32 \mathrm{~V}$ corresponds to the addition of an electron in $\alpha-\mathrm{LUMO}, \mathrm{E}_{\mathrm{LUMO}}=-\left[\mathrm{E}_{-0.32}-\mathrm{E}_{1 / 2 \text { (ferrocene) }}+4.8\right]=-3.6 \mathrm{eV}$, indicating that the first oxido-reduction event takes place at the metallic center Fe(III) in Figure 10.

Also, the manganese complex has almost a comparable calculated molecular orbital energies as the ligand, in addition, the theoretical and experimental gaps of the ligand $\mathrm{LH}_{2}$ and the manganese complex are nearly equal (Table 5), according to the presentations HOMO, LUMO, HOMO-1 and LUMO+1 of complex LMn(III)Cl, the orbitals of the metal and of the ligand are overlapped, figure 10. Thus DFT calculation corroborates the experimental electrochemical data.

Table 6. Experimental and calculated potential.

\begin{tabular}{lccccc}
\hline \multirow{2}{*}{ Compound } & \multicolumn{5}{c}{$\mathrm{LH}_{2}$} \\
\cline { 2 - 6 } & $\mathrm{E}_{\mathrm{pa} 1}$ & $\mathrm{E}_{\mathrm{pa} 2}$ & $\mathrm{E}_{\mathrm{pa} 3}$ & $\mathrm{E}_{\mathrm{pc} 1}$ & $\mathrm{E}_{\mathrm{pc} 2}$ \\
\hline Experimental & -1.60 & 0.90 & 1.20 & -1.50 & -1.77 \\
\hline Theoretical & $/$ & 0.90 & 1.37 & -2.27 & -2.56 \\
\hline
\end{tabular}

\section{Chemical reactivity}

The reactivity of our compounds could be discussed mostly on the basis of its electronic orbitals and their energies [55] which clearly control the various steps of the catalytic cycle. The high values of the respective HOMO energies $\left(\mathrm{E}_{\text {Номо }}\right)-5.265$ and $-5.952 \mathrm{eV}$ for $\mathrm{LMn}(\mathrm{III}) \mathrm{Cl}$ and $\mathrm{LFe}(\mathrm{III}) \mathrm{Cl}$ complexes reflect a low donor character whereas the low values of the respective LUMO energies ( $\mathrm{E}_{\mathrm{LUMO}}$ ) -2.300 and $-3.091 \mathrm{eV}$ reflect an acceptor character in chemical transformations. The relatively small gap 2.965 and $2.861 \mathrm{eV}$ implies low kinetic stability and high chemical reactivity [56] and the negative HOMO and LUMO energies indicate that the complexes are globally predisposed to act as reducing agents. Furthermore, the high values of dipolar moment ( $\mu$ ) 5.796 and $5.471 \mathrm{D}$ of the $\mathrm{LMn}(\mathrm{III}) \mathrm{Cl}$ and $\mathrm{LFe}(\mathrm{III}) \mathrm{Cl}$ complexes is an indicator of a high polarity of the covalent bonds correlating with the molecular distribution of electrons [57]. 
Also, the catalytic rates, for the investigated LM(III)Cl complexes, are linked to the redox potential of the $\mathrm{M}^{+3} / \mathrm{M}^{+2}$ couple during the catalytic cycle. According to the mechanistic hypothesis, the Lewis acidity of the metal (III) center in the metal (II)-oxo intermediate significantly affects the redox potential of the complexes and, therefore, the degree of the catalytic reactivity [58].

Hence, a relationship between the catalytic properties of the complexes and the redox potentials can be established. Since the electronic effects control the reactivity in the catalytic cycle, cyclic voltammetry is a useful tool to investigate the mechanism of the catalysis and for the understanding of the structure/reactivity relationship in our LM(III)Cl complexes. When the half-wave potential values, $\mathrm{E}_{1 / 2}$, approaching the zero value, the activity of the complexes is appreciable in the aerobic oxidation [59]. Herein, The $\mathrm{E}_{1 / 2}$ values of the complexes $\mathrm{LMn}(\mathrm{III}) \mathrm{Cl}$ and $\mathrm{LFe}(\mathrm{III}) \mathrm{Cl}$ are respectively -115 and $-320 \mathrm{mV} / \mathrm{SCE}$, therefore, this would imply that a window of $E_{1 / 2}$ values exists and these values initially favorthe fixation of molecular oxygen by the complexesprior to the start of the effective catalysis.

\section{Catalytic reactions}

The catalysts $\mathrm{LFe}(\mathrm{III}) \mathrm{Cl}$ and $\mathrm{LMn}(\mathrm{III}) \mathrm{Cl}$ complexes oxidize the cyclohexene molecule in presence of molecular oxygen and give the cyclohexene oxides as 2-cyclohexen-1-one, 2cyclohexen-1-ol and epoxy-cyclohexane (table 7 and Figure 13). Both the catalysts are selective to cyclohexen-1-one over the two other oxidation products and this result is revealed by gas chromatography.

From the GC data, it is observed that the $\mathrm{LFe}(\mathrm{III}) \mathrm{Cl}$ and $\mathrm{LMn}(\mathrm{III}) \mathrm{Cl}$ complexes exhibited the highest yield for cyclohexen-1-one, 64 and 60\%, respectively. The iron and manganese complexes are included in the family of "best" catalysts for the oxidation of olefins [55]. Thus, screening for oxidation catalysis using molecular oxygen as the terminal oxidant identified the iron and the manganese complex as the oxidation catalysts is worthy of continued development.

Table7. Catalytic oxidation of cyclohexene with $\mathrm{O}_{2}$ by $\mathrm{LFe}(\mathrm{III}) \mathrm{Cl}$ and $\mathrm{LMn}(\mathrm{III}) \mathrm{Cl}$ complexes.

\begin{tabular}{lccccc}
\hline \multirow{2}{*}{ Catalyseurs } & Time & Conversion & \multicolumn{3}{c}{ Products (\%) } \\
\cline { 4 - 6 } & $(\mathrm{h})$ & $(\%)$ & Epoxy-cyclohexane & 2-Cyclohexen-1-ol & 2-Cyclohexen-1-one \\
\hline $\mathrm{LFe}(\mathrm{III}) \mathrm{Cl}$ & 6 & 96 & 20 & 16 & 64 \\
\hline $\mathrm{LMn}(\mathrm{III}) \mathrm{Cl}$ & 6 & 97 & 23 & 17 & 60 \\
\hline Oxidant free & 6 & - & - & - & - \\
\hline
\end{tabular}




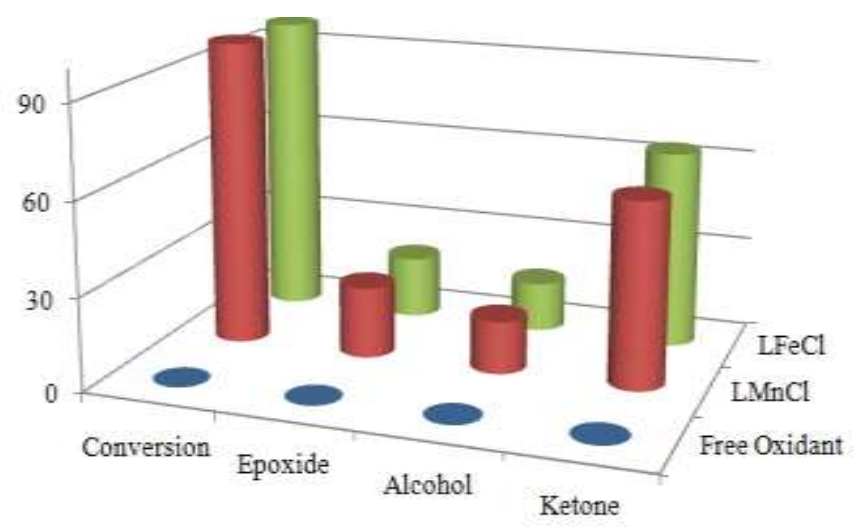

Figure 13. Oxidation of cyclohexene using $\mathrm{LFe}(\mathrm{III}) \mathrm{Cl}$ and $\mathrm{LMn}(\mathrm{III}) \mathrm{Cl}$ catalysts.

The electron-rich cyclohexene has a greater reactivity than the terminal olefins. This reflects the electrophilic nature of the oxygen of the iron-oxo intermediate to the cyclohexene. The proposed mechanism of cyclohexene oxidation catalyzed by the $\mathrm{LFe}(\mathrm{III}) \mathrm{Cl}$ and $\mathrm{LMn}(\mathrm{III}) \mathrm{Cl}$ complexes consists of 3 steps and involves the binding of molecular oxygen and substrate to the iron and manganese complexes (figure 14). Cyclohexene is also a very useful model substrate to study catalytic systems involving $\mathrm{Fe}^{\mathrm{III}} / \mathrm{Fe}^{\mathrm{II}}$ and $\mathrm{Mn}{ }^{\mathrm{III}} / \mathrm{Mn}^{\mathrm{II}}$ system.

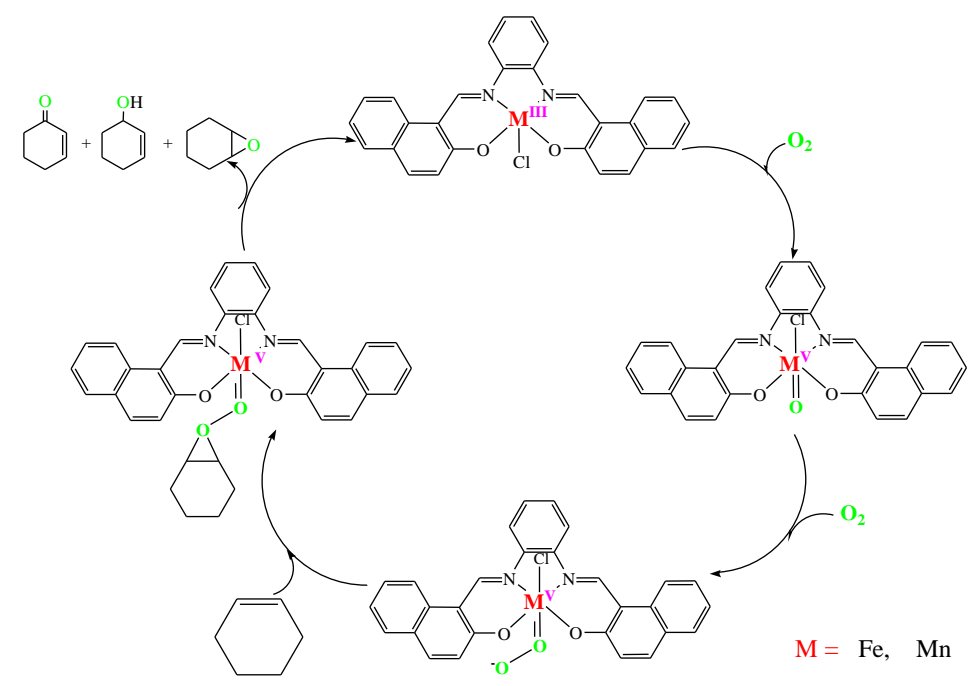

Figure 14. Formation of different intermediate species during the cyclohexene oxidation.

Theoretically, the molecular structures of cyclohexene, epoxy-cyclohexane, 2cyclohexene-1-ol and 2-cyclohexene-1-one were optimized and the electronic energies of the optimized geometries were estimated, Figure 15 shows the electronic energies of the cyclohexene and their oxides, the figure shows clearly that the 2-cyclohexene-1-one molecule is the most stable with the energy $-8399,34 \mathrm{eV}$, this result explains the high selectivity of oxygen for this last, in addition the molecules 2-cyclohexene-1-ol and epoxy-cyclohexane have slightly higher electronic energies about $-8326,69 \mathrm{eV}$ and $8330,77 \mathrm{eV}$ respectively which explain the comparable selectivity and their weak selectivity comparatively to 2-cyclohexen-1-one, finally, 
the high conversion can be explained by the high electronic energy of cyclohexene about $6385,15 \mathrm{eV}$ which proves that this molecule is much less stable than his oxide molecules.

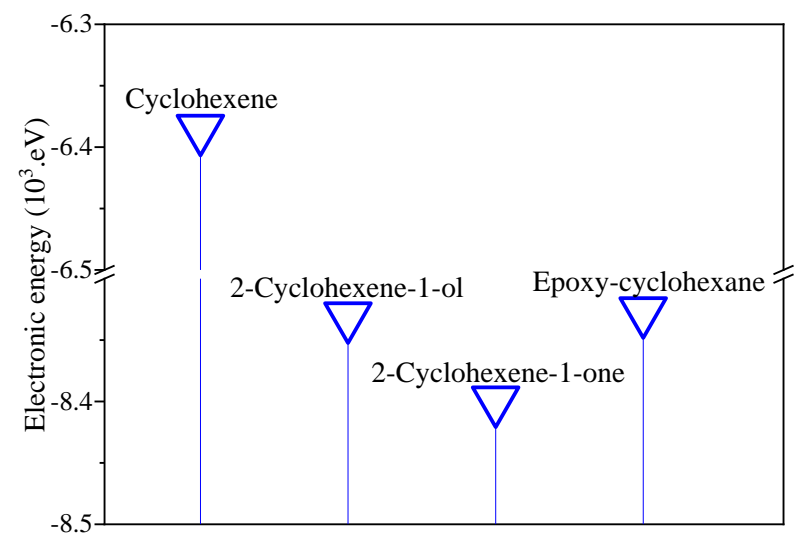

Figure 15. Electronic energies of the cyclohexene and their oxides.

\section{Conclusion}

Iron and manganese complexes of tetradentate $\mathrm{N}_{2} \mathrm{O}_{2}$ Schiff base ligand have been prepared with high purity and good yield $\sim 70 \%$. Spectroscopic analysis confirmed the composition and the structure of the obtained compounds. The X-ray structural study reveals that the ligand $\mathrm{LH}_{2}$ crystallizes in the monoclinic system in the presence of a DMSO molecule. The results of $\mathrm{HS}$ analysis indicate that the major interactions are found to be $\mathrm{H} \cdots \mathrm{H}$ interaction with contributions of $45.9 \%$ of the total area. The geometry of $\mathrm{LH}_{2}$ and the vibrational frequencies of all the compounds are confirmed by the DFT calculations. The complexes show reversible redox processes with $\mathrm{E}_{1 / 2(\mathrm{FeIII} / \mathrm{Fe} \text { II })}=-320 \mathrm{mV} / \mathrm{SCE}$ and $\mathrm{E}_{1 / 2(\mathrm{MnIII} / \mathrm{MnII})}=-115 \mathrm{mV} / \mathrm{SCE}$ by cyclic voltammetry. The corresponding iron and manganese complexes are efficient catalysts in the oxidation reaction of cyclohexene in presence of $\mathrm{O}_{2}$ and the formation of cyclohexene-1-one is the main product. Among all possible products, cyclohexene-1-one shows the highest stability as suggested by the low energy $(-8399,34 \mathrm{eV})$, obtained from DFT calculations.

\section{Declaration of competing interest}

The authors declare that they have no known competing financial interests or personal relationships that could have appeared to influence the work reported in this paper.

\section{Acknowledgement}

The Authors gratefully acknowledge the financial support from The Directorate General for Scientific Research and Technological Development (DGRSDT) in Algeria. They also acknowledge the help to access the NMR Facility and Microanalysis Service at Chemistry Institute of the University of Strasbourg (Unistra), France.

\section{Supplementary Material}


CCDC-770458 contains the supplementary crystallographic data for this paper. These data can be obtained free of charge via www.ccdc.cam.ac.uk/data_request/cif by e-mailing: data_request@ccdc.cam.ac.uk; or by contacting: The Cambridge Crystallographic Data Centre, 12 Union Road, Cambridge CB2 1EZ, UK; Fax: 44(0)1223-336033.

\section{References}

[1] A.T. Taher, H.H. Georgey, H.I. El-Subbagh, Eur. J. Med. Chem. 47 (2012) 445-451.

[2] T. Plech, M. Wujec, U. Kosikowska, A. Malm, B. Kapron, Eur. J. Med. Chem. 47 (2012) 580-584.

[3] P. Zoumpoulakis, C. Camoutsis, G. Pairas, M. Sokovic, J. Glamoclija, C. Potamitis, A. Pitsas, Bioorg. Med. Chem. 20 (2012) 1569-1583.

[4] A. Tarushi, E. Polatoglou, J. Kljun, I. Turel, G.P. Dimitris, P. Kessissoglou, Dalton Trans. 40 (2011) 9461-9473.

[5] S. Murugesan, K. Kirchner, Dalton Trans. 45 (2016) 416-439.

[6] P. Baborova, M. Moder, P. Baldrian, K. Cajthamlova, T. Cajthaml, Res. Microbiol. 157 (2006) 248-253.

[7] J.W. Whittaker, Arch. Biochem. Biophys. 525 (2012) 111-120.

[8] F.C. Friedel, D. Lieb, I. Ivanovic-Burmazovic, J. Inorg. Biochem. 109 (2012) 26-32.

[9] M.W. Vetting, L.P. Eackett, L. Que, J.D. Lipscomb, D.H. Ohlendorf, J. Bacteriol. 186 (2004) 1945.

[10] E.H. Oliw, Prostaglandins Other Lipid Mediat. 68-9 (2002) 313-323.

[11] N.S. Venkataramanan, G. Kuppuraj, S. Rajagopal, Coord. Chem. Rev. 249 (2005) 12491268.

[12] J.R. Lindsay Smith, Y. Iamamoto, F.S. Vinhado, J. Mol. Catal. A: Chem. 252 (2006) 2330.

[13] T.C.O. Mac Leod, V. Palaretti, V.P. Barros, A.L. Faria, T.A. Silva, M.D. Assis, Appl. Catal. A: Gen. 361 (2009) 152-159.

[14] S. Tollari, A. Fumagalli, F. Porta, Inorg. Chim. Acta 247 (1996) 71-74.

[15] A. Rezaeifard, M. Jafarpour, G.K. Moghaddam, F. Amini, Bioorg. Med. Chem. 15 (2007) 3097-3101.

[16] G.B. Shulpin, G. Suss-Fink, L.S. Shul'pina, J. Mol. Catal. A: Chem. 170 (2001) 17-34.

[17] C.W. Tang, S.A. Van Slyke, C.H. Chen, J. Appl. Phys. 65 (1989) 3610-3616.

[18] H. Miyasaka, A. Saitoh, S. Abe, Coord. Chem. Rev. 251 (2007) 2622-2664.

[19] J. Bernadou, B. Meunier, Adv. Synth. Catal. 346 (2004) 171-184. 
[20] M.M.Q. Simões, C.M.B. Neves, S.M.G. Pires, M.G.P.M.S. Neves, J.A.S. Cavaleiro, Pure Appl. Chem. 85 (2013) 1671-1681.

[21] G.G. A. Balavoine, Y.V. Geletii, D. Bejan, Biol. Chem. 1 (1997) 507-521.

[22] G. Franz, R.A. Sheldon, Oxidation, Ullmann's encyclopedia of industrial chemistry; Wiley-VCH, Weinheim, 2004.

[23] T. Punniyamurthy, S. Velusamy, J. Iqbal, Chem. Rev. 105 (2005) 2329-2363.

[24] F. Cavani, J.H. Teles, ChemSusChem. 2 (2009) 508-534.

[25] P.M. Osterberg, J.K. Niemeier, C.J. Welch, J.M. Hawkins, J.R. Martinelli, T.E. Johnson, T.W. Root, S.S. Stahl, Org. Process Res. Dev. 19 (2015) 1537-1543.

[26] E.I. Solomon, S.D. Wong, L.V. Liu, A. Decker, M.S. Chow, Curr. Opin Chem. Biol. 13 (2009) 99-113.

[27] E.I. Solomon, M.L. Neidig, Chem. Commun. 105 (2005) 2227-2252.

[28] J.B. Wittenberg, B.A. Wittenberg, J. Exp. Biol. 210 (2007) 2082-2090.

[29] J.A. Hoy, H. Robinson, J.T. Trent Jr., S. Kakar, B.J. Smagghe, M.S. Hargrove, J. Mol. Biol. 371 (2007) 168-179.

[30] S.N. Vinogradov, L. Moens, J. Biol. Chem. 283 (2008) 8773-8777.

[31] P.R. Ortiz de Montellano, Cytochrome P450: Structure, Mechanism and Biochemistry; Kluwer Academic/Plenum Publisher, New York, 3rd Ed, 2005.

[32] T. Mlodnika, B.R. James, in: F. Montanari, L. Casella (Eds.), Metalloporphyrins Catalytzed Oxidations, Kluwer, Dordrecht, The Netherlands, 1994, pp. 121-144.

[33] M86-E01078 APEX2 User Manual, Bruker AXS Inc., Madison, USA, 2006.

[34] G.M. Sheldrick, SHELXS-97 program for crystal structure determination, Acta Crystallogr. A46 (1990) 467-473.

[35] G. Sheldrick, SHELXL-97, Universit€at Göttingen, Göttingen, Germany, 1999.

[36] M. Dolaz, V. McKee, A. Gölcü, M. Tümer, Spectrochim. Acta, Part a 71 (2009) 1648-1654.

[37] W. Kohn, L.J. Sham, Phys. Rev. 140 (1965) 1133-1138.

[38] A.D. Becke, J. Chem. Phys. 98 (1993) 5648-5652.

[39] C. Lee, W. Yang, R.G. Parr, Phys. Rev. 37 (1998) 785-789.

[40] B. Miehlich, A. Savin, A. Stoll, H. Preuss, Chem. Phys. Lett. 157 (1989) 200-206.

[41] M.J. Turner, J.J. McKinnon, S.K. Wolff, D.J. Grimwood, P.R. Spackman, D. Jayatilaka, M.A. Spackman, CrystalExplorer17.5, (2017). http://hirshfeldsurface.net.

[42] S. Bendia, K. Ouari and L. Karmazin. IUCrData (2017). 2, x170169

[43] K. Ouari, S. Bendia, J. Weiss, C. Bailly, Spectrochim. Acta, Part A 135 (2015) 624-631.

[44] B.T. Thaker, R.S. Barvalia, Spectrochim. Acta, Part A 84 (2011) 51-61. 
[45] A. Rambabu, M.P. Kumar, S. Tejaswi, N. Vamsikrishna, Shivaraj, J. Photochem. Photobiol., B 165 (2016) 147-156.

[46] M. Merzougui, K. Ouari, J. Weiss, J. Mol. Struct. 1120 (2016) 239-244.

[47] S.A. Patil, S.N. Unki, A.D. Kulkarni, V.H. Naik, P.S. Badami, Spectrochim. Acta, Part A 79 (2011) 1128-1136.

[48] M. Khorshidifard, H.A. Rudbari, B. Askari, M. Sahihi, M.R. Farsani, F. Jalilian, G. Bruno, Polyhedron 95 (2015) 1-13.

[49] G. Grivani, A. Ghavami, V. Eigner, M. Dusek, A.D. Khalaji, Chin. Chem. Lett. 26 (2015) $779-784$.

[50] F.H. Allen, O. Kennard, D.G. Watson, L. Brammer, A.G. Orpen. J. Chem. Soc. Prekin trans. II (1987) S1-S19.

[51]Fleming, Frontier Orbitals and Organic Chemical Reactions, Wiley, London, 1976.

[52] S. Majumder, S. Dutta, L. M. Carrella, E. Rentschler, S. Mohanta, J. Mol. Struct. 1006 (2011) 216-222.

[53] M. Amirnasr, M. Bagheri, K. Mereiter, C. R. Chimie 16 (2013) 1091-1097

[54] R. Kannappan, S. Tanase, I. Mutikainen, U. Turpeinen, J. Reedijk, Polyhedron 25 (2006) 1646-1654.

[55] S. Majumder, S. Hazra, S. Dutta, P. Biswas, S. Mohanta, Polyhedron 28 (2009) 24732479. 